\title{
HÄÄBUVA KESKLÜÜDI MURDE JÄLGEDEL SUVEL 2012
}

\author{
PETAR KEHAYOV, EVA SAAR, \\ MIINA NORVIK, ANDRES KARJUS
}

\begin{abstract}
Annotatsioon. Lüüdi keel on üks vähem uuritud ja dokumenteeritud ning samal ajal üks ohustatumaid läänemeresoome keeli. Artikkel esitab ülevaate 2012. aastal kesklüüdi alal toimunud Tartu Ülikooli keeleteadlaste välitööde tulemustest ning on suunatud eelkõige keeleteadlastele, kuid ka ajaloolastele, etnoloogidele ning keelesotsioloogidele. Artikli esimeses osas esitatakse hinnang kesklüüdi murde kõnelejaskonna suuruse kohta tänapäeval. Teine osa sisaldab keelelist analüüsi, mis keskendub hääbuva murde nüüdisaegsele struktuurile - peamiselt fonoloogiale ja morfoloogiale. Toodud andmed täiendavad seniseid teadmisi kesklüüdi murde sisemisest liigendusest. Eraldi tähelepanu pühendatakse ka keelekontakti ilmingutele murdegrammatikas, eelkõige sellistele, mis on teoreetiliselt väljakutsuvad. Artiklis lõpus esitatakse vaadeldava murdeala keelenäiteid.
\end{abstract}

Võtmesõnad: deskriptiivne keeleteadus, ohustatud keeled, keelekontaktid, keele dokumenteerimine, lüüdi keel, fonoloogia, morfoloogia

\section{Lü̈̈̈di lingvistilise, geograafilise ja etnilise mõistena}

\subsection{Lüüdi asustusest ja rahvastikust}

Alates Arvid Genetzi artikli „Wepsän pohjoiset etujoukot” ilmumisest (Genetz 1872-1873) on lüüdid mänginud olulist rolli idapoolsete läänemeresoomlaste rahvastiku- ja keeleajaloo rekonstrueerimisel. Juba Genetzi artikli pealkiri viitab asjaolule, et lüüde peeti kaua vepslasteks ning nende

${ }^{1}$ Ekspeditsioon kesklüüdi alale toimus 16.-25.06.2012 ja selles osales neli uurijat Tartu Ülikooli eesti ja üldkeeleteaduse instituudist. Täname toetuse eest keeleteaduse, filosoofia ja semiootika doktorikooli, Alexander von Humboldti Fondi ning Haridus- ja Teadusministeeriumi riikliku programmi „Eesti keel ja kultuurimälu 2010” granti „Keelealased välitööd Eestis ja Loode-Venemaal”. Artikli valmimise käigus saadud abi eest oleme tänulikud Aleksandra Rodionovale, Irma Mullonenile ja kahele anonüümsele retsensendile. 
keelt vepsa keele murdeks. Sellest arusaamast loobumine võttis aastakümneid: esmalt lahutati vepsa keelest põhja- ja kesklüüdi murded nende märgatava karjalapärasuse tõttu, alles 1932. aastal lahutas Juho Kujola vepsa keelest ka lõunalüüdi murderühma (Kujola 1932; Turunen 1946: 5).

Vepsa ja lüüdi murrete üksteisest eristamine ei lahendanud siiski veel kuulsat lüüdi küsimust - milline on lüüdi murrete asend läänemeresoome keelte klassifikatsioonis (vt Pahomov 1992, 1995, 2011: 10). Soome keeleteaduslikus traditsioonis on lüüdi murdeid vaadeldud karjala-vepsa segamurderühmana (nt Turunen 1947; Virtaranta 1972), nõukogude ja vene keeleteadus on lugenud lüüdi murded karjala keele osaks (Laanest 1975: 20, 26-27; vt ka Pahomov 2011: 10) ning uuemal ajal on lüüdi murdeid käsitatud iseseisva läänemeresoome keelena (Pahomov 1992, 2011: 10). Edaspidises käsitluses räägime kokkuleppeliselt lüüdi keelest, kuid rõhudes ainult mõiste 'keel' sotsiolingvistilisele tähendusele (kogukonna kommunikatsiooni vahendina) ning pretendeerimata seisukohavõtule lüüdi asendi kohta läänemeresoome keelte ja murrete jaotuses.

Tänapäeva lüüdi keele eripära on paljuski tingitud lüüdide etnilise ajaloo keerdkäikudest. Vähemalt XIII sajandini elasid lüüdide praegustel asualadel veel saamid (Pahomov 2011: 12). Lüüdid, kelle esiisad kuulusid vepslaste hulka ja kelle algkodu asus kuskil Laadoga kaguranniku ja Ojati jõe alamjooksu vahel, olid hiljemalt kümnendaks sajandiks hakanud liikuma mööda jõestikke põhja poole. Kolonisatsioon kulges järgmiselt: Sviri jõgi $($ vn Cвирь $)>$ Važeni jõgi $($ vn Важинка $)>$ Pühäjärvi $($ vn Святозеро $)>$ Šuja jõgi (vn Шyя) > Äänisjärv ja sealt edasi mööda väinu Äänisneemele (vn Заонежье) (Pahomov 2011: 16; vt ka Mullonen 2008: 170-216). Migreerudes põhja poole, kohtusid lüüdide esiisad Laadoga ja Äänisjärve vahelisel maakitsusel peale saamide ka Aunuse karjalaste eelkäijatega ning hiljem, umbes XIV sajandil ka lõunapoolsete päriskarjalastega (Pahomov 2011: 17).

Need kontaktid, maastiku eripära ja ilmselt ka hiljem vahele kiilunud vene asustus on tinginud kolme lüüdi murderühma eraldumise: põhjalüüdi (Petroskoist põhja pool, enamasti Äänisjärve väinade vahel), kesklüüdi (Petroskoist edelas, Šuja jõe ja tänaseks hüljatud Kaškana küla vahel) ja lõunalüüdi (Kuujärve ümbruses). Põhjalüüdi murde peamiseks kontaktkeelevormiks läänemeresoome keelte poolt on olnud lõunakarjala murre, kesklüüdi murre on sattunud aga tugeva Aunuse karjala keele mõju alla, lõunalüüdi murderühm on kõige vähem karjalastunud ning kõige lähedasem vepsa keelele (vt Pahomov 2011: 10). 
Arvestades lüüdi asustuse kuju, on lüüdi keele püsimine XXI sajandini lausa mõistatuslik. Lüüdide etnolingvistilisele vitaalsusele on kindlat negatiivset mõju avaldanud nende ajaloolise keeleala piiri pikkuse suhe pindalaga. Tegemist on Tšiili-kujulise maa-alaga, mille pikkus põhjast (Palolampi külast) lõunasse (Kuujärve Paloniemi külani) on umbes $220 \mathrm{~km}$, kuid mille laius idast läände ei ületa kusagil $30 \mathrm{~km}$ (Turunen 1946: 4). Taoline paiknemine on võimaldanud vene asustusel kiiluda lüüdi asustuse vahele, mis omakorda on põhjustanud lüüdi murderühmade üksteisest eemaletriivimise. Uuemal ajal on vene asustuskiil tekkinud piki suuri teid. Selline on näiteks Petroskoi linnast kirdesse minev vene asustuskiil, mis eraldab Šuja alevi ümbruse põhjalüüde ja Viidana külarühma kesklüüde, või Petroskoist kagu suunas teljel Vilga-Matrosõ-Polovina tekkinud vene asustus, mis lahutab Viidana ja Priäžä ümbruse kesklüüde.

Vene asustuse vahelekiilumise ja laienemise üks tagajärgi on olnud lüüdi asustuskeskuste väljalõikamine ülejäänud lüüdi keelealast ja lüüdi keelesaarte sünd. XX sajandi esimesel poolel oli veel alles kaks vene asustusega ümbritsetud lüüdi keelesaart. Üks neist oli Kuujärvest umbes 20 km kirdesse, tänapäeva Leningradi oblasti piiresse jääv Järventakuise keelesaar, kus Aimo Turunen 1943. aastal veel mõningaid lüüdi keele oskajaid kohtas (Turunen 1946: 3-4). Teine, Lohmoioja (ehk Ručja) keelesaar asus 10 km Petroskoist põhja pool. Seal luges Turunen 1944. aastal kokku vaid kuus lüüdi keele oskajat (Turunen 1946: 6). Uurija jaoks on need saared nagu ajaaknad keele ja rahvastiku maastikku enne vene asunduse tekkimist Laadoga ja Äänisjärve vahelisel maakitsusel.

Vene rahvaloendused ei ole arvestanud lüüde eraldi rahvana ega lüüdi keelt eraldi keelena ja seetõttu on igasugused hinnangud lüüdi keele kõnelejaskonna suuruse kohta ette määratud olema umbkaudsed. Kujola (1932) arvestas Venemaa 1905. aastal ilmunud rahvaloenduse tulemuste põhjal lüüdide koguarvuks 10697 kõnelejat, neist üle poole moodustasid põhjalüüdid. Aastatel 1963-1966 lüüdi külades keeleainest kogunud Aleksander Barantsev hindas lüüdi kõnelejaskonna suuruseks 6000-7000 inimest (Pahomov 2003). Aastaks 2003 on Miikul Pahomovi hinnangul lüüdi keele kõnelejate arv vähenenud vähemalt poole võrra (Pahomov 2003), tänapäeval ei ületa see 300-500 piiri (Pahomov 2011: 12). ${ }^{2}$

2 Ühtlasi hindas Pekka Zaikov 2012. aastal Tartu Ülikoolis peetud loengus tänapäeva lüüdide arvu umbes 3000 inimesele (Zaikov 2012). Niisugust lahknevust Pahomovi 
Kuna käesolev uurimus keskendub kesklüüdi murdele, tuleks püüda jõuda selgusele kesklüüdi kõnelejate arvu muutumises viimase aastasaja jooksul. Lähtepunktiks olgu kesklüüdi suuremate külade rahvuslik koosseis Venemaa 1926. aasta rahvaloenduse järgi (vt SNMKA), mis ei eristanud lüüde teistest karjalastest.

Tabel 1. Kesklüüdi suuremate külade rahvuslik koosseis 1926. aastal $(\text { SNMKA })^{3}$

\begin{tabular}{|c|c|c|c|c|}
\hline & Karjalasi & Soomlasi & Venelasi & Muid \\
\hline \multicolumn{5}{|l|}{ Viidana külanõukogu } \\
\hline Üliči & 141 & & 14 & 8 \\
\hline Pogoste & 121 & 7 & 17 & \\
\hline Alaižagd' & 149 & & 2 & 6 \\
\hline Viäčurd'e & 166 & & & \\
\hline Üläižagd' & 105 & & 1 & \\
\hline \multicolumn{5}{|l|}{ Teruküla külanõukogu } \\
\hline Terukülä (Priäžä) & 207 & & & \\
\hline Soavakülä (Priäžä) & 137 & & 2 & \\
\hline Keskikülä (Priäžä) & 99 & & 6 & \\
\hline Präkkä & 103 & & & \\
\hline \multicolumn{5}{|l|}{ Pühäjärve külanõukogu } \\
\hline Pelduoine & 334 & & & \\
\hline Pühäjärvi & 441 & & 43 & 6 \\
\hline Lid'žmi & 153 & & & \\
\hline Sürdjä & 86 & & & \\
\hline \multicolumn{5}{|l|}{ Simaništo külanõukogu } \\
\hline Simaništo & 206 & & 9 & \\
\hline Vašakke & 165 & & & \\
\hline Siidniemi & 217 & & & \\
\hline Kaškan & 321 & 4 & 4 & \\
\hline
\end{tabular}

ja Zaikovi hinnangutes saab ilmselt seletada trükiveaga ja mitte tegeliku lahkarvamusega.

3 Külad on tabelis ja mujal tekstis esitatud nende lüüdikeelse nimekuju järgi; venekeelsed külanimed on toodud allpool 2012. aasta ekspeditsiooni sotsiolingvistilises ülevaates. 
Võib arvata, et ajaloolisel kesklüüdi alal (vt kaart 1) elavatest karjalasteks arvatud inimestest on valdav osa just kesklüüdi murde kõnelejad. Võimalikke sisserännanud Aunuse karjalasi tuleks siiski arvestada vähemalt 10\%-lise marginaalina. Aunuse karjalaste lahutamise koguarvust kompenseerib aga tabelis välja toomata väiksemate külade rahvastik, mis koosnes samuti valdavalt lüüdidest. Jäädes ettevaatlikuks, võime oletada, et 1926. aastal oma ajaloolisel asualal elavate kesklüüdi murde kõnelejate arv ulatus vähemalt 2000 inimeseni. Järgmises peatükis toome võrdluseks ajalooliste kesklüüdi külade lüüdikeelse kogukonna umbkaudse suuruse tänapäeval.

Kaart 1. Kesklüüdi murdeala

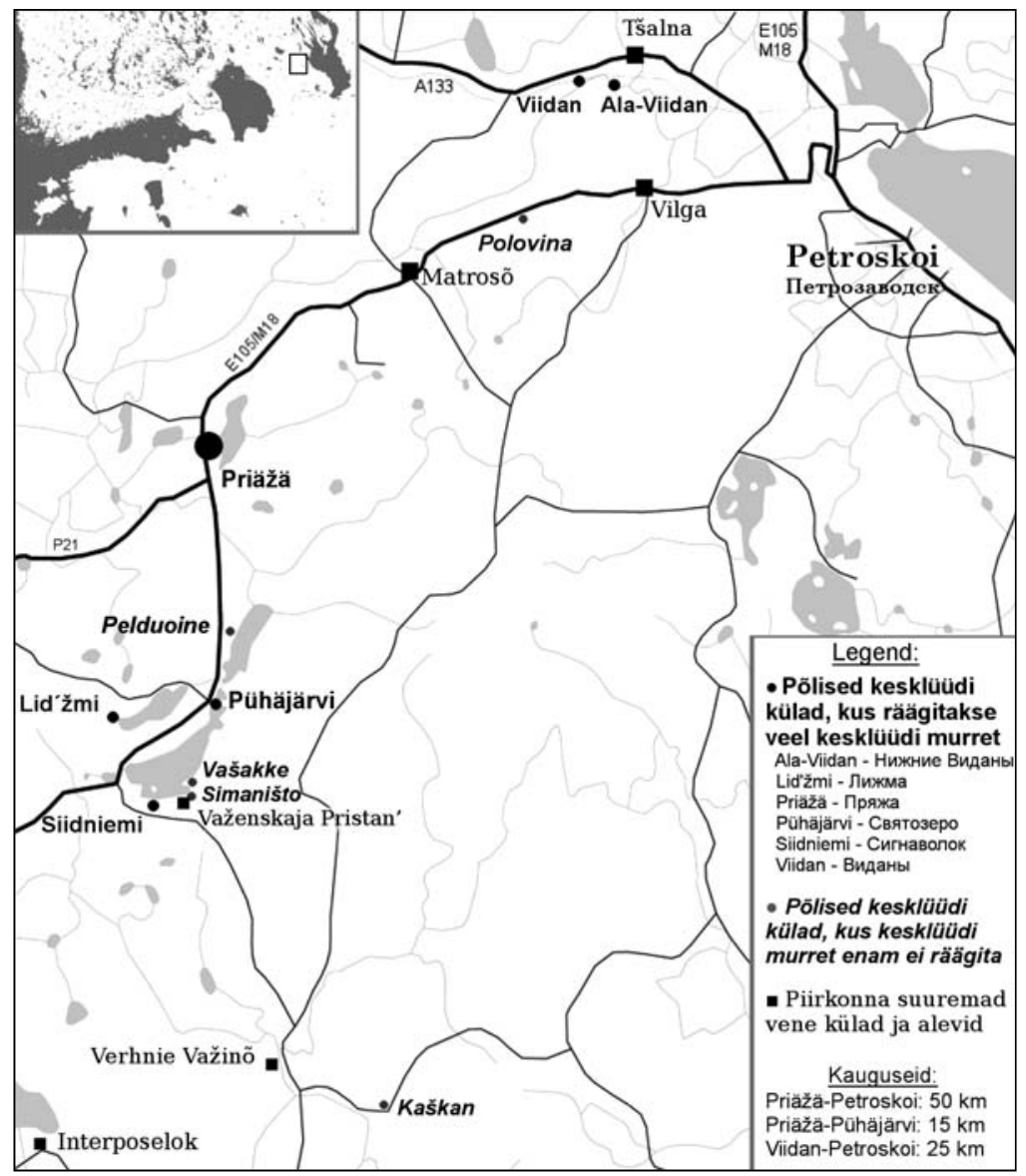




\subsection{Kesklüüdi tänapäev: sotsiolingvistilisi tähelepanekuid}

2012. aasta ekspeditsioonil käisime neljas põlises kesklüüdi asulas, kus kesklüüdi murret veel mõningal määral räägitakse: Viidana külas, Priäžä alevis, Pühäjärve külas ja Lid'žmi külas (vt kaart 1).

Põhjast lõunasse liikudes on esimene neist Petroskoist $20 \mathrm{~km}$ kirdes asuv Viidan (vn Виданьl), mis koos Ala-Viidanaga (vn Нижние Видань) moodustas varem viiest algupärasest Šuja jõe ääres paiknenud külast koosneva külastu: Pogoste (vn Погост), Üliči (vn Антушевская), Alaižagd' 'alaots' (vn Нижние Виданы), Üläižagd' 'ülaots' (vn Кузьминская) ja Viäčurd'e (vn Вячурга) (Mamontova 2002). Tänapäeval on Pogoste, Üliči, Üläižagd' ja Viäčurd'e sulandunud üheks külaks.

Viidana külarühmast umbes $40 \mathrm{~km}$ kagus asub Priäžä alev (vn Пряжa), mis on alla neelanud kolm kunagist kesklüüdi küla: Teruküla, Soavaküla ja Keskiküla. Peterburi-Petroskoi tee äärde jääv Priäžä alev on rajooni keskus ja selle elanike arv on 2010. aasta rahvaloenduse andmetel 3675 inimest. Kohalike elanike sõnul alevi ümber paiknevates külades lüüdi keelt enam ei räägita.

Pühäjärve küla (vn Святозеро) asub $15 \mathrm{~km}$ Priäžäst lõuna pool samanimelise järve ääres. Tänapäeval on Pühäjärve küla kesklüüdi ajaloolisel alal paiknevatest küladest ilmselt kõige suurema lüüdi keele rääkijate arvuga. ${ }^{4}$ Küla on Karjala olude kohta üsna rahvarohke (1000-1400 elanikku). Sinna rajatud loomakasvatussovhoosi tõttu on ta endasse koondanud ka ümbruskonna külade elanikke. Pühäjärvest ja kahest väiksemast järvest koosneva järvistu ümbrus on ajaloo vältel olnud kesklüüdi alal kõige tihedama asustusega piirkond. Sinna on kuulunud sellised lüüdi külad nagu Simaništo (vn Симаништо), Siidniemi (vn Сигнаволок), Kuare $\sim$ Kuara (vn Kapa), Vašakke (vn Вашаково), Pelduoine (vn Пелдожа), Lahta (vn Лахта), Nirkka (vn Нирка), Palatesd'ärvi (vn Палатоозеро), Prokku (vn Прокка), Hedotišto (vn Плоскозеро), Sürdjä (vn Сюрьга) ja Tšarniemi (vn Чарнаволок). Pühäjärve küla lüüdide sõnul on nimetatud külad tänapäeval kas täiesti tühjad või asustatud vaid suvel ja lüüdi keele kõnelejaid neis enam ei leidu. Nimekirja kuulub ka Lid'žmi (vn Лuжмa) küla, kus meiegi käisime, kuna kuulsime, et üks lüüdikeelne perekond elab seal aasta ringi ning suveks kolib sinna veel paar sealtkandist pärit lüüdi.

4 Selles külas on ka varem eesti keeleteadlasi käinud. Pühäjärvelane VS meenutas, et tema juures käis Tartu Ülikooli karjala keele õppejõud ja uurija Kene Noormägi. 
Peale mainitud kesklüüdi asulate käisime ka Pühäjärvest umbes 20 km lõunas paiknevas, pärast sõda rajatud vene külas Verhnie Važinõs (lüüdi Vuažnend'ogi), kuhu on kolinud lüüde sellest seitse kilomeetrit kagupool asuvast, tänaseks tühjaks jäänud Kaškana külast (vn Кашканьl).

\subsubsection{Kõnelejate arv}

Tabelis 2 anname umbkaudse hinnangu ajaloolisel kesklüüdi alal elava kesklüüdi murde kõnelejaskonna suurusele. See hinnang põhineb meie küsitletud kesklüüdi murde kõnelejate andmebaasis olevatel nimedel (vt tabeli 2 teine veerg). Tuleb siiski märkida, et kuigi püüdsime igas asulas sotsiaalseid võrgustikke hästi kindlaks teha (küsides alati sugulaste ja teiste sama asula lüüdi keelt kõnelevate inimeste nimesid), on võimalik, et mõni kesklüüdi murde rääkija ei tulnud meie küsitletutele meelde (eriti tõenäoline on see rahvarohkes Priäžä alevis).

Peale selle tuleb arvestada ka nende kesklüüdidega, kes elavad küll ajaloolisel kesklüüdi alal, kuid vene külades. Viimaseid on kahte tüüpi: juba sajandeid tagasi tekkinud vene asulad või nõukogude kollektiivmajanduse algusaegadel tekkinud asulad, nagu Verhnie Važinõ. Kuna me ei käinud sellistes asulates nagu Matrosõ, Važenskaja Pristań ja Interposelok, ei julge me teha järeldusi seal elavate kesklüüdi murde kõnelejate arvu kohta. Võib ainult arvata, et võõras keskkonnas on lüüdi keel ununenud kiiremini kui mujal ja selle kõnelejaid on nendes asulates tänapäeval vaid mõni üksik. Verhnie Važinõs leidsime kaks kesklüüdi murde rääkijat; peale selle saime teada, et Matrosõ küla vanadekodus elab üks Viidanast pärit lüüd.

Et jõuda tegelikkusele võimalikult lähedase kesklüüdi murde kõnelejate arvuni, lugesime kokku Svetlana Kovaleva ja Aleksandra Rodionova sotsiolingvistilises uurimuses (2011: 129-132) toodud keelejuhtide nimekirjas nimetatud inimesed, kes on pärit kesklüüdi alalt ja elavad veel seal, kuid keda ei ole meie keelejuhtide nimekirjas. ${ }^{5}$ Asjakohased numbrid on esitatud tabeli 2 kolmandas veerus; liites teise ja kolmanda veeru numbrid, saime kõnelejate koguarvu, mis on tegelikkusele ilmselt suhteliselt lähedal. Hoolimata meie Pühäjärve informantide tõdemusest, et Siidniemes lüüdi keelt enam ei räägita, on Kovaleva ja Rodionova keelejuhtide hulgas

\footnotetext{
5 S. Kovaleva ja A. Rodionova (2011: 129-132) ei märgi alati informantide keelt, kuid nimekirjas esinevate inimeste emakeel täpsustati isiklikus kirjavahetuses Rodionovaga.
} 
neli Siidniemes elavat lüüdi (Kovaleva ja Rodionova andmed põhinevad aastatel 2009-2011 tehtud välitöödel).

Tabel 2. Teadaolevate kesklüüdi murde kõnelejate arv põlistes kesklüüdi asulates ${ }^{6}$

\begin{tabular}{|l|c|c|c|}
\hline \multicolumn{1}{|c|}{ Asula $^{6}$} & $\begin{array}{c}\text { TÜ 2012. aasta } \\
\text { ekspeditsioon }\end{array}$ & $\begin{array}{c}\text { Kovaleva ja Rodionova } \\
\text { ekspeditsioonid }\end{array}$ & Kokku \\
\hline Ajaloolised lüüdi külad & & 10 \\
\hline Viidana külarühm & 10 & 12 & 23 \\
\hline Priäžä & 11 & 9 & 26 \\
\hline Pühäjärvi & 17 & 1 & 6 \\
\hline Lid'žmi & 5 & 4 & 4 \\
\hline Siidniemi & \multicolumn{5}{|}{} \\
\hline Vene külad & \multicolumn{3}{|l}{} \\
\hline Verhnie Važinõ & 2 & 26 & 2 \\
\hline Matrosõ & 1 & & 1 \\
\hline Kokku & 46 & & \\
\hline
\end{tabular}

Kuigi toodud arvud on kindlasti puudulikud, võib üsna suure kindlusega öelda, et 2012. aastal ei ületa ajaloolisel kesklüüdi murde alal elavate kesklüüdi kõnelejate arv sadat inimest. ${ }^{7}$ Kui tahaksime arvutada kesklüüdide arvu kogu maailmas, tuleks arvestada ka väljaspool kesklüüdi ala elavate kesklüüdidega, eelkõige nendega, kes elavad linnades (Petroskois, Aunuses ja Peterburis), ning nendega, kes on rännanud Soome.

\subsubsection{Keelejuhid}

Ekspeditsioonil intervjueerisime 17 kesklüüdi murde kõnelejat. Peale Viidanast, Priäžäst, Pühäjärvest ja Lid'žmist pärit keelejuhtide oli nende hulgas ka Pelduoise, Palatesd'ärve, Prokku ja Kaškana külades sündinud inimesi. Hiljuti ilmunud Kuujärve murdekogumikus oletab Miikul

${ }^{6}$ Mõned informandid elavad suvel ühes asulas ja ülejäänud aja teises; nende elukoht on märgitud küsitlusaja järgi.

7 Seda veendumust jagab ka Venemaa Teaduste Akadeemia Karjala Teaduskeskuse professor Irma Mullonen (isiklik informatsioon). 
Pahomov, et Kaškana murrak on välja surnud (Pahomov 2011: 10). Me leidsime kolm Kaškanast pärit lüüdikeelset inimest (kaks neist elavad Verhnie Vazinõs ja üks Lid’žmis), kellest kahte ka küsitlesime. Näiteks suvel Lid'žmis ja talvel Pühäjärves elav AM rääkis meile väga sujuvas keeles Kaškana minevikust: külapidudest, lastemängudest ja palgiparvetamisest Važeni jõel.

Meie keelejuhid esindasid eri astmeid keelesurma kontiinumil (vt Dorian 1977; Campbell, Muntzel 1989; Sasse 1992). Nende hulgas oli soravaid rääkijaid (ingl fluent speakers); unustajaid (ingl forgetters) ehk kõnelejaid, kes on keeleomandamise perioodil saanud piisava sisendi ja on kunagi olnud soravad rääkijad, kuid kes väheste kommunikatsioonivõimaluste tõttu peavad kulutama palju energiat, et meenutada sõnu, moodustada lauseid ning siduda neid narratiiviks; poolkõnelejaid (ingl semi-speakers), kelle kokkupuude lüüdi keelega sisendkeelena on olnud ebapiisav ja kelle keeleoskus on seetõttu puudulik; ning mäletajaid (ingl rememberers), kes suudavad meenutada ainult isoleeritud fraase. Kõige noorem murde rääkija oli viiekümnendates eluaastates Pühäjärve elanik LM, keda võib iseloomustada poolkõnelejana.

\subsubsection{Murde hääbumist põhjustavad tegurid ja keelelised hoiakud tänapäeval}

Kesklüüdi murde hääbumine on geograafiliste, majanduslike, demograafiliste ja ajalooliste tegurite koosmõju.

Geograafiliste tegurite seas on ehk otsustavaim Petroskoi linna lähedus. ${ }^{8}$ Alal on rohkesti Petroskoi elanike suvilaid ning seetõttu kasvab sealsete külade elanikkond suvel märgatavalt. Olulisemad Petroskoisse viivad maanteed asuvad kesklüüdi alal: lääne-ida suunas Soomest tulev Helsinki-Lappeenranta-Petroskoi maantee ja lõuna-põhja suunas Peterburi-Petroskoi-Murmanski maantee. Oma ligipääsetavuse tõttu on kesklüüdi piirkond lüüdi asustuse nõrgim lüli, samas kui lõunalüüdi asustus jääb suurtest teedest kõrvale ja põhjalüüdi külad asuvad raskesti ligipääsetavate Äänisjärve väinade vahel. Paradoksaalsel kombel on suured maanteed toiminud pigem kesklüüdi asustuskeskuste vaheliste ühenduste lõhestajana. Keelejuhtidega vesteldes jäi mulje, et Priäžä-Pühäjärve lüüdide mentaalsel

8 Tähelepanuväärselt tähendab kesklüüdi murdes sõna lidne ilma atribuudita ühemõtteliselt Petroskoid. 
kaardil Viidana põlislüüdi külarühma justkui ei eksisteeri. Selles on süüdi see, et kuigi Priäžä ja Viidana vahel on linnulennult umbes vaid $30 \mathrm{~km}$, puudub nende vahel otsetee ning sõita tuleb sinna suure ringiga Petroskoi äärelinna kaudu.

Majanduslike tegurite hulgast võib esile tõsta kesklüüdi piirkonna suhteliselt suure industrialiseerituse. See puudutab eelkõige Viidana ümbrust ning Priäžä alevit oma väiketööstusega. Viidana külarühm kuulub Tšalna-Petroskoi-Šuja tööstuspiirkonda, kuhu kuulus üks Karjala Vabariigi omaaegseid suurimaid metsamajandeid, Šuja-Viidana lespromhoz. Ainult mõne kilomeetri kaugusel Viidana külarühmast on suur sõjaväelennubaas, mille hävituslennukite harjutusi saime jälgida keelejuhtide hoovidest. Viidana piirkonna tööstusmaastikku kujundab ka Soome (Joensuu) - Petroskoi raudtee, mis on andnud tööd ka lüüdidele. Viidana elanik AK teenis eluaeg leiba raudteetöölisena ning meie üllatuseks suutis ta oma erialast üsna soravalt ka lüüdi keeles rääkida.

Üks traditsiooniline tegevusala, mis varem kesklüüdi asustusi omavahel ning kesklüüde lõuna- ja põhjalüüdidega sidus, oli palgiparvetamine Važeni ja Šuja jõel. Kaškanast pärit AR ja AM mäletasid hästi, kuidas Kaškana ja põhjapoolseima lõunalüüdi küla Metšuońiemi vahel palki parvetamas (splavnois) käidi; AM oli isegi parvetajana töötanud. Kuigi neid külasid lahutab ligi $30 \mathrm{~km}$ laiune metsavöönd, hoiti splavnoi's sõlmitud suhteid üleval teineteist pühade ja pulmade ajal külastades. Vahemaast hoolimata (samuti umbes $30 \mathrm{~km}$ ) käisid kaškanalased tihedalt läbi ka oma kesklüüdi hõimukaaslastega Pühäjärve ümbrusest; AM lausus meile järgmise tšastuška, kus võrreldakse Simaništo ja Kaškana poisse.

kaškanan_d'o kujoižed on kurgeližed aidaižed kaškanan_d'o brihaižil on satinaižet paidaižed simaništon brihaižil kujoižed on kivi_kives kińdi simaništon brihaižed on ribu^ribus kińdi

'Kaškana õuedel on ju kaunistatud aiakesed, Kaškana noormeestel on ju satiinist särgikesed. Simaništo noormeestel teed on kivi kivis kinni, Simaništo noormehed on kalts kaltsus kinni.'

Kesklüüdi külade hääbumises on suurt rolli mänginud nende lähedusse kerkinud sovhoosikeskused ja tööstusasulad. Viidana lähedale ehitati metsamajandi keskusena Tšalna asula, kuhu tuli elama venelasi ning 
peamiselt USAst 1930. aastatel Venemaale emigreerunud soomlasi. Važenskaja Pristańi ehitamine mõjus lähedal asuvale Simaništo külale laastavalt, Verhnie Važinõ metsapunkti ehitamisel oli Kaškana külale samasugune mõju ning Priäžä alev neelas alla Teruküla, Soavaküla ja Keskiküla. Sovhoosi- ja kolhoosiasulate rajamine mitte olemasolevatesse küladesse, vaid mõni kilomeeter nendest eemale põhjustas kesklüüdide massilise kolimise uutesse keskustesse, mille tagajärjel said neist samasugused sisserännanud nagu kaugetest Nõukogudemaa nurkadest tulnud inimestest. Oma kodukülast paari kilomeetri kaugusel elavad siseimmigrandid ei tundnud enam suurt vajadust oma emakeelt lastele edasi anda. Tänapäeva kesklüüde saab iseloomustada tööstuslik-põllumajandusliku eluviisi ja maailmatunnetusega alevielanikena, kes kuuluvad 260000 elanikuga Petroskoi majanduslikku ja sotsiaalsesse orbiiti.

Karjala Vabariik on kogu nõukogude ajal olnud sisserändemaa, kuhu on tulnud suurel hulgal inimesi Lõuna-Venemaalt, Valgevenest, Ukrainast ja Tatarstanist. Teine demograafiline tegur, mille mõju kesklüüdi keelele on olnud salakavalam kui Nõukogude Liidu sisene (sunnitud või vabatahtlik) immigratsioon lõunast, on kontakt soome ja Aunuse karjala keelega. Aunuse karjala keeleala jääb kesklüüdi murdealast läände. Vieljärve ja Säämäjärve ümbruse rahvarikkad Aunuse karjala külad on peale teist maailmasõda toitnud rohkem industrialiseeritud Priäzä alevit ja ViidanaTšalna piirkonda Aunuse päritolu sisserändajatega. Selle tulemusena elab tänapäeval Priäžä alevis rohkem Aunuse karjala kui lüüdikeelseid inimesi. Oma lühikeste visiitide jooksul õnnestus meil kohata juba aastakümneid Viidanas ja Pühäjärves elavaid Aunuse karjala keele rääkijaid. Näiteks Viidanas õpetab lastele karjala keelt Nuosjärvelt (vn Крошнозеро) pärit Aunuse karjalasest lasteaiaõpetaja. ${ }^{9}$ Selle kõige tagajärg on kesklüüdi murde nivelleerumine Aunuse karjala keele poole. Kõige enam on seda tunda Priäžä alevis, mida saab tänapäeval käsitada segakeelse alana.

Olulisi mõjureid kesklüüdi murde jätkusuutlikkusele saab otsida ka piirkonna XX sajandi ajaloost. Üks selline on Soome okupatsioon aastatel 1941-1944. Ida-Karjala vallutamine soomlaste poolt säästis palju inimelusid (eelkõige näljasurmast evakuatsioonioludes), kuid keelelises mõttes oli selle mõju pigem negatiivne. Jätkusõja lõpus läks osa kesklüüde taganeva Soome armeega Soome ja kaotas nõnda kontakti oma

9 Miikul Pahomov (2003) märgib, et emakeele asemel võõraste karjala murrete õpetamine lüüdi koolides on sagedane nähtus. 
keelekeskkonnaga. Olulisemad tagajärjed olid aga asjaolul, et lüüdi lapsed õppisid kolm aastat lähisugukeelses koolis. Soome koolis käinud keelejuhid kasutavad erisõnavara ja soomekeelseid väljendeid, mis omakorda lööb sassi nende kesklüüdi murde süsteemi. Seda trendi on võimendanud soome keele soosimine sõjajärgsetel aastatel, eriti Karjala-Soome NSV ajal (1940-1956).

Kui Soome okupatsioon oli keelele ohtlik, siis evakuatsioon oli eluohtlik. Enamik meie keelejuhtidest oli sõja-aastatel evakuatsioonis Sise-Venemaal. Paljud pühäjärvelased ja priäžälased sattusid Arhangelski oblastisse, viidanalasi viidi Baškiiriasse (osa ka Komi ANSV-sse) ning kaškanalasi Kirovi oblastisse. Evakuatsioonis tehti rasket füüsilist tööd ja kannatati pidevat nälga, mille tagajärjel oli suremus suur, eriti väikelaste seas. Tähelepanuväärne on see, et meie keelejuhtide hulgas ei olnud inimesi, kes oleks sündinud aastatel 1935-1941. Ilmekas näide toimunu kohta on 1933. aastal sündinud Viidana elaniku VP saatus. Tema pere evakueeriti Baškiiriasse, evakuatsiooni üleelanuna tuli neil sõja lõpus tagasiteel veeta mõni kuu Karjala Vabariigis Segeži linna lähedal. Seal surid nälga noorem vend ja õde, meie keelejuht ise pääses näljasurmast üle noatera.

Lõpuks esitame mõned tähelepanekud kesklüüdide keelehoiakute ja maailmavaatelise tausta kohta. Kesklüüdide maailmatunnetuses mängib ristiusk väiksemat rolli kui lõunapoolsetel läänemeresoome õigeusklikel rahvastel (nagu setudel, vadjalastel ja isuritel). Pühasenurgad, mis Petserimaal ja Ingerimaal on peaaegu kohustuslikud, on kesklüüdi alal väga haruldane nähtus. Sama haruldane on kirikus käimine, sest nõukogude ajal hävitati peaaegu kõigi meie nähtud külade kirikud.

Ühtlasi ei ole võimalik täheldada, et keele säilimise aste korreleeruks religioossusega või traditsioonilise maailmapildiga. Me kohtasime ideelistest kommunistidest keelejuhte, kes olid nõukogude ajal töötanud vastutusrikastel ametikohtadel ja reisinud palju Nõukogude Liidus, kuid kelle keel oli hästi säilinud ning kes olid head informandid ka traditsioonilistes eluvaldkondades, nagu toiduvalmistamine või külapühad. Näiteks Pühäjärves elav VS oli olnud asula parteiorganisatsiooni sekretär ja reisinud töö tõttu palju, kuid sellest hoolimata oli ta üks paremaid keeleoskajaid. Priäžä keelejuht MT oli aastakümneid töötanud sovhoosidirektorina ja olnud üle neljasaja eri rahvusest inimese ülemuseks.

Kesklüüdi murde üldine staatus on madal. Näiteks Viidanas elavad naabrid AK ja NP, kes meiega rääkisid lüüdi keeles, suhtlevad omavahel 
üksnes vene keeles. Kõnekas on asjaolu, et kui palusime kesklüüdi informantidel oma keeles midagi laulda, siis laulsid nad tavaliselt Aunuse karjala või soome keeles. Ometi võis vanema põlvkonna hulgast leida inimesi, kes oma keelt väärtustavad, nagu näiteks VS Pühäjärvest. Kui ütlesime, et meile väideti, et Pühäjärve külas ei ole enam lüüde järel, lausus tema järgmised sõnad.

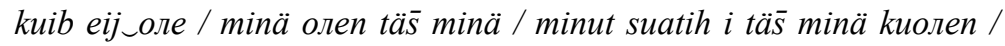
Pühärves // mиато_da_i tātto ol'dih karjalaižet / vot / da_i mina oлen / i_minä ainos pagižemme vot / $\underline{i}$ da hot' tuлоu / müö ainos pagižemme l'ü̈diks //

'Kuidas ei ole? Mina olen. Siin mind saadi ja siin ma suren, Pühäjärves. Ema ja isa olid karjalased, vot ja mina olen. Ja mina, me räägime alati lüüdi keelt. Vot Ida kui tuleb, me alati räägime lüüdi keelt.'

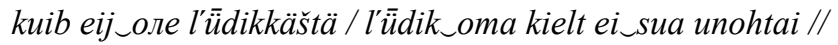

'Kuidas ei ole lüüde? Lüüd oma keelt ei saa unustada!'

\section{Keelelisi märkmeid kesklüüdi murdealalt}

Kesklüüdi murde (tänapäevase olukorra) kirjeldamisel lähtume Turuneni (1946) pakutud lüüdi murdeala sisemisest liigendusest, mis jagab kesklüüdi murde kolmeks murrakuks: Viidan põhjas, Teru-Priäžă ${ }^{10}$ keskel ja Pühäjärvi lõunas (kuhu paigutuvad kõik murrakud Pelduoise ja Kaškana vahel). Et Pühäjärves on (uuemaid) muutusi, mis puuduvad lähedal asuvate Lid'žmi ja Kaškana külade keelejuhtidel, siis toome oma käsitluses selle piirkonna välja neljandana. ${ }^{11}$ Ekspeditsioonil kogutud keeleainestik võimaldab rohkemate või vähemate erijoonte alusel eristada kesklüüdi murde sees nelja piirkonna keelt: 1) Kaškana (Ka) ja Lid'žmi (Li), 2) Pühäjärvi (Pü), 3) Priäžä (Pr) ja 4) Viidana (Vi).

Selleks, et anda tänapäeva kesklüüdi murdest kompaktsem ülevaade, keskendume murdele iseloomulikele joontele ühelt poolt nende säilimise seisukohast keele hääbumise staadiumis, teisalt aga oleme registreerinud

${ }^{10}$ Kuigi tänapäeval pole võimalik eristada Teru-Priäžä ja Soava-Priäžä keelekasutust, on varem seda tehtud (vt Turunen 1946: 26-30).

${ }^{11}$ Pekka Zaikovi uurimus ,,Verb karjala keeles” hõlmab muu hulgas lüüdi murdeid, seejuures jagab autor lüüdi keele nelja murderühma: põhjalüüdi, kesklüüdi, lõunalüüdi (Pühäjärve ümbrus) ja Kuujärvi (михайловский диалект) (vt Zaikov 2000: 19-29). 
mitmeid kesklüüdi murdes toimuvaid muutusi ja uuendusi, millele varasemates keele kirjeldustes viited puuduvad. Samuti vaatleme naabruses kõneldavate läänemeresoome keelte ja murrete ning vene keele kontakti ilminguid.

Peatüki lõpus esitame nimetatud piirkondade kohta tekstinäiteid, mis on valitud ekspeditsioonil kogutud materjalide seast.

\subsection{Kesklüüdi murdejoonte säilimine ja muutumine}

\subsubsection{Konsonantism}

Lüüdi keele ajaloolist kuulumist algvepsast võrsunud keelte hulka saab täheldada eelkõige konsonantismis (Pahomov 2011: 10).

Kesklüüdi (ja lüüdi üldiselt) astmevaheldus piirdub kvantitatiivse klusiilide astmevaheldusega, nt $\left(\mathrm{Ka}-\mathrm{Li}, \mathrm{AM}^{12}\right)$ aitte : aitan 'ait : aida'. Muudel juhtudel ei ole silbi kinnisus kvantitatiivset ega kvalitatiivsest opositsiooni põhjustanud (Turunen 1946: 111-136; Kettunen 1960: 22-23), nt (Li-Pr, IT) halgod 'halud (küttepuud)'; (Ka-Li, AM) andetti 'anti'; (Pr, MT) rindal 'vastas'; (Pü, VS) elgeńd'i 'taipas, sai aru'; (Vi, VS) l'ähten 'lähen'. Üks kõigile lüüdi murretele ühine joon, mis on omane ka vepsa keelele, kuid mida Aunuse karjala keeles üldiselt ei leidu, on vokaalidevaheliste üksikklusiilide - $g-,-b$ - ja - $d$ - esinemine kinnise silbi alguses (Turunen 1946: 25), nt (Li-Pr, IT) veded 'veed'; (Ka-Li, AM) regeл 'reel, saaniga'; (Pr, MT) lugen 'loen'; (Pü, VK) mägel 'mäel'; (Vi, VS) poigad 'poisid'. Priäžä murrakus, kus võiks eeldada Aunuse karjala keele mõjul ulatuslikumat astmevaheldust, domineerivad samuti astmevahelduseta vormid, nt (Pr, AG) itken 'nutan', tahton 'tahan'; (Pr, KV) peldod 'põllud', kandetti 'kandsid'. Nende kõrval võis samadelt informantidelt kuulda vaid üksikuid nõrgaastmelisi vorme, nt (Pr, AG) hevol 'hobusel, hobusega', külvein 'ujusin' (vrd Viidana külben 'ujun'). Aunuse karjala mõjuks saab pidada liikvida ja palataalklusiili ühendi astmevahelduse näidet (Pr, AG) jallai 'jalgsi' (vt Itkonen 1971: 158).

Viidana murrakus täheldasime isikuliste asesõnade vormides nõrka astet, nt (Vi, VS) meijäy külä 'meie küla'. Asesõnade nõrgaastmelisi

${ }^{12}$ Sulgudes on kõigepealt esitatud piirkonna lühend, mis kandi keelt näide esindab (sidekriipsuga ühendatud piirkondade korral tähistab esimene keelejuhi sünnikohta, teine praegust elukohta), seejärel on toodud keelejuhi initsiaalid. 
vorme on Turunen (1946: 117) pidanud omaseks Soava-Priäžä murrakule ja kõigile naabruses kõneldavatele Aunuse karjala murretele, meid'en-tüüp aga iseloomustab põhjalüüdi murret ja Lohmoioja murrakut. Meie andmestikus on näiteid meid'en-tüüpi asesõnade tarvituse kohta siiski ka kesklüüdi murde lõunapoolses osas, seejuures on asesõnade teise silbi vokaal piirkonniti erinev, vrd (Li-Pr, IT) meid'eり küläspiäi 'meie külast', heid'ey küläs 'nende külas' (samalt keelejuhilt registreerisime ka ühe nõrgaastmelise vormi meijen) ja (Pü, VS ja VK) meid'än 'meie'.

Nagu naabruses kõneldavatele murretele on ka lüüdi keelele iseloomulik heliliste üksikkonsonantide, palatalisatsiooni ning afrikaatide rohkus: (Ka-Li, AM) ruaduoi 'töötas', kui linduine leńdin 'lendasin nagu linnukene', t'šilahaized 'nõgesed'; (Li-Pr, IT) mańd'ž́uoid 'maasikad'; (Pü, VK) pagiži 'rääkis'; (Pr, KV) pühärve t'š́upus 'Pühäjärve kandis', lind'žoi 'lillakas, linnumari'; (Vi, NP) ńägin 'nägin'; (Vi, VS) neit'šskkainé 'neiu'.

Kesklüüdi murdes on muutus * $\boldsymbol{t} \boldsymbol{i}>\boldsymbol{s i}$ verbide minevikuvormides üldiselt tundmata. Siinkohal eristub Viidana keelekasutus teiste vaadeldavate kesklüüdi murrakute omast, sarnanedes pigem põhjalüüdi murdega. Näiteks vormid ruadoin 'töötasin', ruadoi 'töötas' on tarvitusel Lid'žmis, Pühäjärves ja Priäžäs, Viidanas aga esinevad vastavalt ruažin 'töötasin', ruaži 'töötas', samuti t'iezi 'teadis', elgenzin 'sain aru'. Tugevaastmeline vorm ruad(u)oin on tegelikult tavaline nii lõuna-, kesk- kui ka põhjalüüdi murdes. Kujola (vt LmS: 366-367) registreerib nõrgaastmelise vormi ruožin ainult Nuomoilas, mis jääb põhjalüüdi alale, Viidanast mitte väga kaugele. Samas Viidana kohta esitab ta vormi ruaduoin. Seega on võimalik, et nähtus on hiljuti levinud Nuomoilast Viidana kanti.

Nii lüüdi keeles kui ka põhja- ja osalt keskvepsa murdes, aga ka Aunuse karjala keeles on sõnaalguline $\boldsymbol{j}$ muutunud $\boldsymbol{d}^{\prime}$-ks (Turunen 1946: 318): (Li-Pr, IT) d'änöid 'jäneseid; (Ka-Li, AM) d'argai 'jalgsi', d'uoksin 'jooksin'; (Pü, IS) d'älges voinad 'peale sõda'; (Pü, VS) d'oga kezä 'iga suvi', (Pü, VK) d'ügei 'raske', d'ärvelle 'järvele'; (Vi, VS) sinne d'äin 'jäin sinna', d'ätetti 'jäeti'. Muutusele on allunud ka vene laenud, nt (Pü, VS) d'orššit 'kiisad' < vn ëpm. Siiski saab täheldada teatavat ebajärjekindlust. Meie keelejuhtide kõnes kipub $d^{\prime}$ ja $j$-i esinemus varieeruma ennekõike järvi-lõpulistes kohanimedes, sagedane on kadu (vrd Turunen 1946: 318): (Li-Pr, IT) a mama oli palatesd'ärves 'ema oli Palatesjärvest', paltozjärven külä 'Palatesjärve küla'; (Ka-Li, AM) noužjärven nuožarven 
da 'Nuošjärve, Nuošjärve, jaa (taga)', poige vaśśa el'ä pühärvez 'poeg Vasja elab Pühäjärves'.

Informantide kõnest leidub näiteid muutuse $\boldsymbol{j}>d^{\prime}$ kohta ka sõna keskel konsonandi järel, nt $r j>r d$ ': (Li-Pr, IT) mard'ah käüdi 'marjul käidi'; (Pü, VK) sürd'äs 'Sürjäs'; (Pr, MT) mard'oyke 'marjadega'; (Pr, KV) kird'oi 'Kirjak (lehma nimi)'. Hääbuvaid keeli iseloomustab analoogiaseaduse suurenenud roll morfofonoloogias (Sasse 1992: 66, 71), nii on ootamatu $j>d$ ' asendus $l$-i järel (Ka-Li, AM) SgP ńel'd'ä 'nelja' seletatav $r j>r d^{\prime}$ asenduse analoogiaga. Sellises positsioonis on Turuneni (1946: 322) andmetel ootuspärane pigem $l j>l^{\prime} l^{\prime}$, mida ka meie keelejuhid üldiselt kasutavad, nt (Pü, VS) vel'l'en kodis 'venna kodus'. Huvitavat võrdlusmaterjali pakub aga vepsa keel, kus osalt on toimunud muutus $j>$ $g$ ning idavepsa murdest on üles tähendatud ka muutust $l j>l g$, nt vel'ǵed 'vennad' (vt Tunkelo 1946: 476).

Kogutud materjalist ilmneb, et kõigile kesklüüdi piirkondadele on omane metatees häälikü̈hendis $\boldsymbol{n h}$ : (Pü, VS) vahnembi 'vanem', (Ka-Li, AM; Pr, MT) vahnin 'vanim'; (Vi, VS) vahna 'vana'.

*eta-noomenite ainsuse nimetava käände vormi lõpus on kesklüüdi murdes -ei (Turunen 1946: 27): (Ka-Li, AM) levei 'lai'; (Pü, VK) d'ügei 'raske'; (Pü, IS) kibei 'valus'. Ülejäänud paradigmas on *-eta säilinud: (Li-Pr, IT) SgAd oigedal kädel 'paremat kätt'; (Ka-Li, AM) korgedad 'kõrged'; (Pü, VS) d'äredät 'paksud', vargedad vinad 'valget viina'. Siinkohal eristub aga sama tüüpi sõnade vormistik Priäžä keelejuhil, kes tarvitab Aunuse karjala päraseid vorme: (Pr, KV) SgP d'äreidü 'paksu', d'ügeidü 'rasket (tööd)', aga ka vargiedu 'valget', sogied važad 'sõgedad vasikad'.

\subsubsection{Vokalism}

Kui konsonantismis kohtab pigem vepsapärasusi, siis vokalismis on märgata enam ühisjooni Aunuse karjala keelega. Näiteks on nii lüüdi kui ka Aunuse karjala keelele iseloomulik diftongi esinemine rõhulises silbis algupärase pika $\bar{a}, \bar{e}, \bar{o}$ ja $\bar{o}$ asemel, vrd mua $\sim$ muo vs. vepsa ma 'maa' (Kettunen 1960: 25).

Kõigile lüüdi murretele, samuti Aunuse karjala ning vepsa keelele on iseloomulik diftongide $\boldsymbol{a i}, \boldsymbol{u i}, \boldsymbol{o i}$ teise komponendi kadu $\check{\boldsymbol{s}}(\check{z})$ ees sõna esimeses silbis, kui järgnev silp algab klusiiliga (Turunen 1950: 35-37), 
nt (Ka-Li, AM) kūštošt vuotta 'kuuteist aastat'; (Li-Pr, IT) muštan 'mäletan'; (Pü, VK) ei ni meidän daže buabod muštettu 'isegi meie vanaemad ei mäletanud'; (Vi, VS) paštoi leibäd 'küpsetas leiba'. Lüüdi murretele eriomane joon on aga $u$-, $i$-ja $\ddot{u}$-alguliste triftongide esinemine $i$-lõpuliste diftongide asemel (Turunen 1950: 42-45). Selle kohta kogusime mitmeid näiteid: (Ka-Li, AM) ruaduoi 'töötas', süöimme 'sõime', suain 'sain'; (Li-Pr, IT) lontsapiäi 'Olonetsi poole'; (Pü, VS) kanuoid 'kanu'. Siinkohal saame kinnitada Turuneni tähelepanekut, mille järgi nimetatud joont ei kohta Soava-Priäžäs - triftonge ei registreerinud me ühegi Priäžä keelejuhi kõnest.

Vaadeldaval lüüdi keelealal on säilinud vokaalharmoonia, kuigi selle puhul saab täheldada mõningast ebajärjekindlust. Nimetatud joone poolest paigutub keelekuju Aunuse karjala (kus vokaalharmoonia on järjekindel) ja vepsa keele (kus vokaalharmoonia puudub, v.a $\ddot{a}$-harmoonia) vahele. Meie keelejuhtidest esineb vokaalharmooniat rohkem Pühajärve ja Priäžä piirkonna inimestel, nt (Pü, VS) a tämä vähäšte tännepiä on 'aga see on natuke siiapoole'; (Pr, KV) minä en nähnü 'mina ei näinud'. Ometi leidub neiski piirkondades varieeruvust, nt Pühäjärve keelenäites (vt osa 2.2.3.1) esineb sõna kirik nii kujul kirikkö, kirikko kui ka kirik. Priäžäs elava Lid'žmist pärit keelejuhi kõnest võib tuua järgmised näited: (Li-Pr, IT) l'ǘd'ikkoi l'üd'ikköi 'lüüdid', lähtedā lähtedä 'lähevad'. Kõige sagedamini tuleb ebajärjekindlus vokaalharmoonia puhul esile Viidana keelejuhtide kõnes, nt (Vi, VS) a tädä ei ni pidä sanoda 'aga seda ei pea jutustama', mina елаn 'mina elan', (Vi, NP) müö етme ńähnü 'me ei näinud', a ńügü ńi kedä еi оле ni keda 'aga nüüd ei ole kedagi, kedagi', $\underline{t s ̌ a l n a} \sim \underline{t s ̌ a ̈ l n a}$. Selgub, et sarnane oli olukord ka aastakümneid varem: Turunen (1946: 29-30) märgib, et vähem ulatuslik vokaalharmoonia on üks tunnusjooni, mis lähendab Viidana murrakut Nuomoila omale ja sedakaudu põhjalüüdi murdele.

Kahe- ja enamasilbiliste noomenite lõpul on nominatiivis ja konsonanttüveliste sõnade ainsuse partitiivis toimunud muutus $\boldsymbol{a}, \ddot{\boldsymbol{a}}>\boldsymbol{e}$, seda juhul, kui eelmine silp on pikk (vt ka Turunen 1950: 157-158). Nimetatud noomenite ülejäänud paradigmas $a$ säilib. Näiteks (Ka-Li, AM) aitte 'ait', vrd aitan 'aida'; (Pü, VS, MV) hukke 'hunt', poige 'poeg'; (Vi, VS) tädä lohte 'seda lõhet', kolmašte 'kolmandat', üheksa laste 'üheksa last'; (Vi, NP) vahne 'vana', hüvä ilme 'ilus ilm'. Sama muutus on aset leidnud ka hilistes vene laensõnades, nt (Ka-Li, AM) pl'emja·nnikke (< племянник) 
'vennapoeg', vrd pl'e·mjannikkad 'vennapojad'; (Pü, VK; Vi, VS; Vi, NP) vunukke (< внук) 'lapselaps', vunukkad 'lapselapsed'; (Vi, VS) ribakke (< рыбак) 'kalamees', kлӣbe (< клуб) 'klubi', pogoste (< погость) 'kirikuküla'.

Priäžä keelejuhtidel enamasti ning Pühäjärve keelejuhtidel mõnevõrra harvem esineb selles positsioonis mõnikord ka Aunuse karjala pärane $\boldsymbol{a}$, $\ddot{\boldsymbol{a}}>\boldsymbol{u}, \ddot{\boldsymbol{u}} \mathrm{nt}$ (Pü, VK) aittu 'ait'; (Pü, IS) päivu paštou 'päike paistab'; (Pr, KV) kolmattu 'kolmandat'. Kõnealust muutust on Turunen (1946: 37) ja Virtaranta (1972: 21) täheldanud ennekõike kesklüüdi Soava-Priäžä murrakus, seega on Aunuse mõju tänapäeval laienenud. Üks vorm, mille kaudu muutus $a, \ddot{a}>u$, $\ddot{u}$ on levimas kogu kesklüüdi alale, on Aunuse karjala pärane essiiv: (Pü, VS) bohatannu 'rikkana'; (Vi, VS) bugalterannu 'raamatupidajana'.

Vaadeldava sõnalõpulise vokaali varieerumist on kesklüüdi alal ohtrasti. Näiteks sõna vuozi 'aasta' ainsuse partitiivis on esindatud nii algupärane (Vi) vuotta, (Li, Ka, Pü, Vi) e-line vuotte, Aunuse karjala tüüpi (Pr, KV) vuottu ning redutseerunud lõppvokaaliga (Pü, VK) vuottô. Nagu vokaalharmoonia peegeldab ka kesklüüdi lõppvokaali varieerumine murde positsiooni Aunuse karjala ja vepsa keele vahel. Aunuse karjala lõppvokaalide $u$ ja $\ddot{u}$ tekkimise ühe võimalusena on Itkonen (1971: 172-173) kirjeldanud vepsapäraste redutseerunud lõppvokaalide -â ja -ə korvamist täisvokaalidega $u, \ddot{u}$.

Kesklüüdi murdele on omane lõpukadu mitmel puhul (vt lisaks Turunen 1950: 155-156; Kettunen 1960: 24). Järgnevalt mõned näited:

1) lõpukadu nii ainsuse kui ka mitmuse partitiivis: (Ka-Li, AM) kaksi poigad kолте tüdärd 'kaks poega, kolm tütart'; (Li-Pr, IT) meil oli pereh viš heyged 'meil oli pere - viis inimest'. Viidana informandid kasutavad aga kõrvuti lõpukaoliste partitiivivormidega neid vorme, kus partitiivi lõpp on säilinud: vrd nt (Vi, VS) aigad 'aega', d'oged 'jõge', aga samas pü̈t'tih kalada 'püüti kala'.

2) lõpukadu kohakäänetes inessiivis, elatiivis, adessiivis ja ablatiivis (Laanest 1975: 103-106; elatiivi ja ablatiivi kohta vt ka osa 2.1.3): (Ka-Li, AM) SgIn lid'nas 'linnas'; SgEl minä it'še olen kaškanas 'mina ise olen Kaškanast', SgAd ehtar 'õhtul', PlAd heboir 'hobusega', SgAbl mujalpiäi 'mujalt'; (Pü, VS) SgAd rindal 'vastas'; (Pü, PK) SgEl evakua tsias '(tulime) evakuatsioonist'. Siinkohal eristub meie materjalis teistest taas Viidana murrak, kus lõpukaoliste vormide kõrval tuleb esile 
ka lõpukaota vorme (eriti adessiivis) ja redutseerunud vokaaliga lõppe: (Vi, VS) SgIn kod'is 'kodus', SgAd таталла 'emal', тіллә 'minul', tоižеллә 'teisel'.

$\boldsymbol{e}$ on labialiseerunud (kunagise) labiaalkonsonandi ees kindla kõneviisi ja potentsiaali ainsuse 3. isikus nii soome idamurretes, karjala, vepsa kui ka isuri keeles (Laanest 1975: 82), vepsa keeles isikulõpu labiaalkonsonant aga säilib $(*-p i>-b)$. Kogutud keelenäidete hulgas on juhtumeid, kus $e$ on labialiseerunud ning esineb lühikese või pika vokaalina, nt (Ka-Li, AM) tänne dorog lähtö'sinna tee läheb'; (Li-Pr, IT) PotSg3 lähtenö 'võib-olla läheb'; (Pr, KV) kitkö релdoлоil 'rohib põldudel'. Sagedane on Aunuse karjala pärane moodustusviis, kus tüvevokaali $e$ asemel esineb ainsuse 3. isiku vormides diftong ou, ö̈ (vt ka Zaikov 2000: 48-49): (Li-Pr, IT) PotSg3 lähtenō lähtenou 'võib-olla läheb'; (Pü, VS) IndPrSg3 tилои 'tuleb', itköu 'nutab', ajelou 'sõidab', pihaл pimenöü 'õues pimeneb'; (Vi, VS) mänou 'läheb', lienou 'leeb, on (tulevikus)'.

\subsubsection{Tähelepanekuid morfoloogia kohta}

Komitatiivi väljendatakse sekundaarse käändega, mis on arenenud genitiivi lõpule - $n$ liitunud postpositsioonist kera, nt (Li-Pr, IT) vo-jenneidegke 'sõjameestega', poigayke 'pojaga'; (Pü, VK) ei keneyke 'mitte kellegagi'; (Pr, KV) јиталауke 'jumalaga, hüvasti'; (Vi, VS) kūzi риолеђke vuotte 'kuus ja pool aastat'; (Vi, NP) lehmigke 'lehmadega'. Kõnealune käändelõpp on lähtunud vepsa keelest (vepsa kerdaл 'kaasas' $>k e$, murdeti leiduvad ka -kel, -ked, -ken) ning levinud peale lüüdi murrete ka Aunuse karjala keeles (Kettunen 1960: 46). Sel teel moodustunud formatiivi on üles tähendatud ka Tveri ja Novgorodi oblasti karjala keele murrakutest. Seal on algkujuna esitatud kегалла ning -nke kõrval täheldatud vorme -nkeла, -nkelä (Palmeos 1962: 37; vt ka Laanest 1975: 110). Ka kesklüüdi murdealal võib täheldada varieeruvust. Ennekõike Pühäjärve keelejuhtide kõnest on leida postpositsioonilist konstruktsiooni: (Pü, VS) kartoffey_ker 'kartulitega'; (Pü, VK) minä heidey kera ainos karjalaks pagižin 'mina nendega ainult karjala keeles rääkisin'. Teistest piirkondadest märkisime üles keu-, kel-lõpulist komitatiivi: (Li-Pr, IT) verkkoloideykeu 'võrkudega', veneheideykel 'paatidega', a kezäl suolatah sovaykel 'suvel (või) soola-

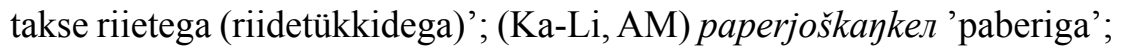

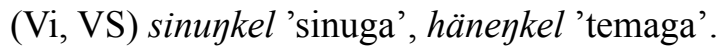


Sarnasusi lüüdi ja vepsa keele vahel on Turunen (1946: 87) täheldanud elatiivi kasutuses: tavapärane on lisada sekundaarne käändelõpp, mis on kujunenud suunda märkivast postpositsioonist (vepsa $p \bar{a} i, p \bar{a}, p a i)$. Taolist moodustusviisi kohtab vähem Pühäjärve ja Soava-Priäžä murdes, rohkem on seda põhjapoolsemates murretes ja Kuujärve murdes, milles on muidu ka kõige enam vepsapärasusi (Turunen 1946: 87). Meie Pühäjärve keelejuhtide kõnest jääb silma see, et elatiivi puhul on varieeruvust ka praegu, seda ühe keelejuhi kõneski. Sealjuures on varieeruvust nii käändelõpu valikus kui ka selle foneetilises kujus (sama on täheldanud Turunen 1946: 87; vt ka tekstikatket osast 2.2.3.2): (Li-Pr, IT) a mama oli palatesd'ärves .. se oli meijey güläspiäi viis kilomedrid 'aga ema oli Palatesjärvest .. see oli meie külast viis kilomeetrit'; (Pü, VK) pīterispiäi 'Peterburist', oblastispiä 'oblastist'; (Pü, VS) lidnaspiäi / lidnast tai pīterist 'linnast, linnast ehk Peterburist'.

Nagu elatiivist, moodustatakse postpositsiooniline kääne ka ablatiivist, ent selle kohta napib kogutud keelematerjalis näiteid: (Ka-Li, AM) SgAbl da i mujalpiäi sid oli rahvas 'ja ka mujalt siis oli rahvast'.

Muu hulgas oleme üles tähendanud instruktiivivorme. Esineb nii $n$-lõpuga kui ka $n$-lõputa instruktiiv. Ka Turunen (1946: 282) toob välja asjaolu, et leidub üksikuid $n$-i kaoga vorme. Instruktiivi mõlemad moodustusviisid on tänapäevalgi lüüdi keelejuhtide kõnes rohkelt kasutusel: (Ka-Li, AM) haugoin lämmädän 'halgudega (puudega) kütan'; (Li-Pr, IT) viidei 'viiekesi', seitšemin lapšin oli vižin lapšin oli '(kellel) seitse last oli, (kel) viis last oli'; (Pü, VS) dāže kaksin lehmiń pid'ettih 'isegi kahe lehma kaupa peeti'; (Pü, VK) d'algai astuimme lidnaspiäi 'jala astusime linnast'.

Omadussõnade keskvõrde tunnuseks on - $m b(i)$. Kogutud keeleandmestiku varal võib öelda, et sõnalõpuline $i$ on järjekindlalt kadunud ennekõike Lid'žmi taustaga keelejuhi kõnes, vrd nt (Li-Pr, IT) külmemb 'külmem'; (Ka-VV'13, AR) nuorembi 'noorem', (Pü, VS; Pr, KV) vahnembi 'vanem', enämbi 'rohkem'. Võrdluskäändena esineb 1) partitiiv, nt (Ka-VV, AR) kolme vuotte minud nuorembi 'minust kolm aastat noorem'; (Pü, VK) üheksad vuotta on hän nuorembi minut 'ta on minust üheksa aastat noorem'; (Pü, VS) enambi ka kolmedkümmenkahte oli utšenikad 'rohkem kui kolmkümmend kaks oli õpilasi'; (Vi, VS) a toine vahnembi on täd̈̈ 'aga teine on temast vanem'; 2) ablatiiv, nt (Pr, KV) vahnen

${ }^{13} \mathrm{VV}=$ Verhnie Važinõ. 
тіпилda 'minust vanem'; 3) elatiiv (koos sekundaarse käändelõpuga), nt (Vi, VS) hän on siga vahnembi meijan roduspia 'ta on seal kõige vanem meie suguvõsast'. Omakeelse võrdlussidesõna $k a$ 'kui' kõrval võidakse tarvitada vene toorlaenu tšem (< vn чем 'kui'), nt (Pü, VS) kalat ljubin enämbä tšem lihat 'kala armastan rohkem kui liha'.

Ülivõrde kohta on näiteid nii analüütilisest kui ka sünteetilisest moodustusest: (Li-Pr, IT) no kaikie subbimb pereh oli viis heyged 'kõige väiksem pere oli viis inimest'; (Vi, VS) mina oлеn kaikkid vahnen nü̈gü 'mina olen nüüd kõige vanem'; (Ka-Li, AM) kaikkis paras 'kõigist parim'; (Pr, MT) vahnin iz mužikois 'meestest vanim'.

Kuigi kesklüüdi murderühma sees näib sageli võimalik vastandus Pühäjärvi ja Priäžä vs. Viidan, on võimalik ka Pühäjärve murde eristumine teistest. Pühäjärve erijooneks on peetud näiteks $i$-lõpulisi infinitiivivorme, mis tulevad esile $a$ - ja $\ddot{a}$-tüveliste verbide puhul (Turunen 1946: 119). Turunen märgib, et $i$-lisi infinitiivivorme ei leidu muudes lüüdi murretes ega ka teistes sugulaskeeltes. Seda joont võib pidada kõige püsivamaks ja see eristab Pühäjärve murrakut kõige ilmekamalt muudest kesklüüdi murrakutest. Pühäjärvest pärit keelejuhtide kõnest registreerisime järgmised näited: (Pü, VK) eläi 'elada', maksai 'maksta', vedäi 'vedada'; (Pü, VS) ongittai 'õngitseda', unohtai 'unustada'. Ülejäänud murdealal on tarvitusel infinitiivivormid lõpuga -ta, -tä, (-da, -dä): (Ka-Li, AM) d'uosta 'joosta', mändä 'minna'; (Vi, VS) ostada 'osta', pidäü heid süöttä da juotta da lüpsädä $i$ sinne ajada 'tuleb neid sööta ja joota ja lüpsta ja sinna ajada'.

Siirdudes verbi juurde võib täheldada, et kesklüüdi murre erineb vahetus naabruses kõneldavast Aunuse karjala keelest mitmuse 1. ja 2. isiku pöördelõppude poolest, mis kesklüüdi murdes moodustatakse - $(m) m e$ ja -tte abil: pagižemme 'räägime', keräžimme 'korjasime', tahtoizime 'tahaksime', ruadoitte 'töötasite'. Aunuses ning selle mõjul ka Soava-Priäžäs on Turuneni (1950: 161) andmetel kasutusel -mmo, -tto. Priäžäs sündinud ja kasvanud keelejuhil, kes abiellus Kindahale (Aunuse küla) ja elas seal enne Priäžässe tagasipöördumist 36 aastat, ilmneb Aunuse karjala keele mõju mitmuse 1. isiku pöördelõppude kasutuses: ta tarvitab vaheldumisi vorme олетте ја олетто, samas on huvitav, et mitmuse 2 . isiku vormid on järjekindlalt lüüdipärased: олеtte 'olete', ruadoitte 'töötasite', nägitte 'nägite'. Mõnevõrra ootamatu oli sama nähtus Pühäjärves elava, oma keele eripärast väga teadliku Aunuse karjalase keelepruugis - mitmuse 1. isiku vormides kasutas ta järjekindlalt lõppu -mmo, mitmuse 2 . isiku vorm aga 
esines tal lüüdipärasena kujul -tte, nt ruavoitte 'töötasite'. Siiski leidus ka põliste pühäjärvelaste kõnes kohati mmo-lõpulisi vorme, nt (Pü, VS) stroimmo $\sim$ stroimme 'ehitasime'.

Tingiv kõneviis on tänapäevalgi väga elav. Tuleb esile näiteid nii oleviku- kui ka perfektivormide kohta (sh $n u$-elemendiga moodustatud perfektist), nii sünteetilisest kui ka analüütilisest moodustusest: (Vi, VS) KndPr sanozin 'ütleksin'; (Pr, AG) IpsKndPr stobi händä koirat süödäis 'et teda koerad sööksid'; (Pü, VS) eslib ńügü oldaiž sukset minä andaižin omal vunukkal 'kui mul oleksid praegu suusad, ma annaksin need oma lapselapsele', IpsKndPf oldanuiž 'olnuks'; (Pü, VK) KndPf voinuiž ajai 'võinuks sõita', KndPfNg müö emme tulnuiž 'me ei tulnuks'; (Pü, VS) KndPf oi minut keran olnuiž süönü 'oi mind oleks ka ära söönud'. $n u$-line konditsionaali perfekt on vepsa, lüüdi ja Aunuse karjala ühisjoon (Kettunen 1960: 21).

Käskiva kõneviisi ainsuse 2. isiku vorm on markeerimata, nt (Pr, KV) sano 'ütle', ištu 'istu', kat'śso 'vaata'. Mitmuse 2. isiku lõpp on -gat, -gät (-kkat, -kkät). See on joon, mis lähendab lüüdi murdeid vepsa keelele (Laanest 1975: 153, 170; Zaikov 2000: 200; Zaiceva 2002: 133-134). Seejuures esitab Pekka Zaikov Pühäjärve keelenäidetes mitmuse 2. isiku vormid säilinud lõppvokaaliga, nt andagatte 'andke', kaččogatte tänne 'vaadake siia' jne (Zaikov 2000: 200). Meil õnnestus registreerida vaid vepsapärase moodustusega vorme, nt (Pü, VK) sanot'tih što elägät te täs 'öeldi, et elage teie siin'; (Pü, VS) d'ogat 'jooge'; (Pr, KV) mengät 'minge'; (Vi, VS) mengät opastukkat edeллеh 'minge õppige edasi'.

Potentsiaal (tunnus -ne-) on tegevuse võimalikkust ja tõenäosust väljendav kõneviis, mis osas Karjala murretes on võrdlemisi tavaline, vepsa keeles esineb aga harva (Laanest 1975: 155). Märkisime informantidelt üles mitmeid potentsiaali näiteid, mis tähendab, et selle joone poolest on kesklüüdi murre lähemal karjala keelele kui vepsa keelele. Ka Zaikovi (2000) uurimuses leidub mitmeid potentsiaali näiteid kesklüüdi murdealalt. Kõige sagedamini esineb seda peamiselt tuleviku koopulana käituva liettä-verbi osana ( $\mathrm{Sg} 3$ lienou), nt (Vi, VS) vīskümmen kūzi vuotte lienou täl vuodel '56 aastat täitub sel aastal', ent on ka teisi näiteid, nagu (Vi, NP) i müö bol'še ne lähtenemme 'ja meie rohkem ei lähe (tõenäoliselt)'. Mitmel korral võis täheldada potentsiaalivormi kasutamist tingimuslauses, nt (Li-Pr, IT) lähtenō / no lähtenou ka minä lähten sid häney_ker kahtē 
'kui tema läheb, no läheb, siis mina ka lähen temaga kahekesi'. Taolised potentsiaalivormi sisaldavad tingimuslaused on tavalised ka karjala ning vepsa keeles (Forsberg 2003: 148; Kettunen 1943: 470).

Läänemeresoome keelte silmapaistvamaid iseärasusi on eri muutevormidega eitusverb (Laanest 1975: 158), mis enamikus läänemeresoome keeltes paikneb põhiverbi ees. Erandiks on võru ja setu keeleala KaguEestis (vt nt Iva 2007: 102), vepsa keel (Zaiceva 2002: 75), aga ka meie käidud lüüdi ja Aunuse karjala keeleala (vt ka Zaikov 2000: 138-142). Läänemeresoome keeltes suhteliselt harva esinevast tagaeitusest leidub näiteid kõigis kesklüüdi piirkondades ja pea kõikide meie poolt küsitletud informantide kõnes, nt (Pü, VK) hän kestänü ei 'ta ei pidanud vastu'; (Pr, $\mathrm{KV})$ kat'śso älä 'ära vaata', mis on ühtlasi näide imperatiivi tagaeituse kohta (vt ka osa 2.2.4). Seejuures saab täheldada, et tagaeitust kasutatakse eriti topelteituse konstruktsioonis, mis sisaldab ka vene eituspartiklit (vt $n i$ verbi < vn не 'ei'): (Vi, VS) ni mid̈̈ олпи еi / tulimme kod'it palettih ni mida оле еi 'midagi ei olnud, tulime, majad põletati maha, midagi ei ole'; ning siis, kui eitusele langeb lausefookus (st eitamist tahetakse eriti rõhutada): (Ka-Li, AM) a kelle sano uskota ei što karjaraks opastetti 'aga kellele öelda, need ei usu, et karjala keeles õpetati'.

Kesklüüdi murdes moodustatakse verbi refleksiivseid vorme selliselt, et refleksiivne liide lisatakse verbi isikulõpule (pezemös 'pesin ennast'), seevastu põhjalüüdi murdes lisatakse refleksiivne liide otse verbitüvele (pezezen 'pesen ennast') (Turunen 1946: 28). Meie keelejuhtide kõnes esineb mitmel juhul verb 'sündima' refleksiivsena kujul rodimuos $\sim$ rodimmos 'sündisin'. Huvitav on see, et kesklüüdi alale jäävas Viidanas sündinud ja kogu elu seal elanud keelejuhil esineb põhjalüüdipärane moodustus, nt rodizuin 'sündisin'. See võib olla veel üks joon, mis on jäänud Turunenil märkamata ja mille poolest Viidana murrak sarnaneb põhjalüüdi murdega. Kesklüüdi murde sarnast refleksiivsete vormide moodustust on Elena Bogdanova (2003) täheldanud ka Aunuse karjala keeles, mida kinnitab meie registreeritud Aunuse karjala keelejuhi lause kindahaz rod'immos $i$ Kindahaz kazvoin 'Kindahas sündisin ja Kindahas kasvasin'.

Vepsa keelega ühine joon on inhoatiivne (tegevuse algust märkiv) verbisufiks -škanden/-škaden. Seejuures vormi -škanden on peetud omaseks lõuna- ja kesklüüdi murretele ning vormi -škaden põhjalüüdi murretele (Turunen 1946: 236, vt ka Virtaranta 1972: 25). Meie keelejuhtidest kasutas sufiksit (ootuspäraselt škanden-kujulisena) vaid üks Pühäjärvest 
pärit keelejuht ning sedagi vaid lauses no sanotah što itše vrode palaškanzi / no ambut'ti da kaik palaškanzi 'no öeldakse, et ise hakkas põlema, no tulistati ja kõik hakkas põlema'. Seega ei tule esile ühtegi näidet selle kohta, kus škanden-/škaden-sufiks tähistaks tegevuse algust tulevikus, nagu лugeškandemme 'hakkame lugema', ruadaškanden 'hakkan töötama' (vt Turunen 1946: 25, 236), või saaks koguni tulevikutõlgenduse, nagu vepsa keeles võimalik (vt Kettunen 1960: 24-25). Üks vaadeldava tuletussufiksi harva esinemise põhjuseid võib olla see, et on kaks verbi, mille abil on samuti võimalik algust tähistada: zavod'ida ja rubeta. Üldiselt tarvitab üks inimene nii üht kui ka teist verbi, nt (Pü, VS) sorok pjätoil vuodel zavodīn opastuta tehnikumah '1945. aastal hakkasin õppima tehnikumis'; kirikko rubetah stroimmah 'kirikut hakatakse ehitama'. Kas ja kuidas sufiksi -škanden/-škaden kasutusala on kokku tõmbunud ning millal tarvitatakse verbe zavod'ida ja rubeta, vajab siiski edasist uurimist.

Kuigi tulevikulise tegevuse algust väljendavad üldiselt verbid zavod'ida ja rubeta, osutuvad kõige huvitavamaks tuleviku väljendamisel verbid liettä ja rod'ida/rod'izetta. Esimese neist saab tagasi viia vanale soome-ugri tüvele, mis läänemeresoome algkeeles on ilmselt esinenud kujul *lée- Tavaliselt on seda tüve seostatud tulevikuliste ja modaalsete tähendustega (Majtinskaja 1973). Pühäjärve keelejuhid kasutasid seda paaril korral, kuid üksnes koos interrogatiivpronoomeniga indefiniitses liitasesõnas: (Pü, VK) konz lienne ${ }^{14}$ ammui se jo oli ülen ammui 'kunagi ammu see juba oli, väga ammu'; Lid'žmist pärit Priäžä keelejuht tarvitas seda korra kesksõnatarindis, väljendades kahtlust (ta kahtles, mis aastal ta Priäžässe elama tuli): (Li-Pr, IT) sorok pjätoil vuodel lienen tилnu '45. aastal vist tulin'. Enim tuleb esile näiteid verbi liettä kasutuse kohta Viidana keelejuhtide kõnes, kus sel on muuhulgas täita tuleviku koopula funktsioon, nt (Vi, VS) seitšemänkümmen kūzi jo lienou 'saab juba 76'; (Vi, NP) kons klubnikad liettah vaлmihet 'millal maasikad saavad valmis?', mit't'e iлma huomen lienou 'missugune ilm homme tuleb?'.

Verb rod'ida/rod'izetta 'sündima' on aga vene laen (< poдumьcя 'sündima'), mis on tuleviku väljendusvahendiks hakanud kujunema ka Aunuse karjala keeles (vt nt Tauli 1966; Metslang 1996). Kesklüüdi murdes leidub seda verbi mitmes funktsioonis: nii oma algses tähenduses, tuleviku koopulana kui ka liitpredikaadi koosseisus (vt alljärgnevaid

${ }^{14}$ Vrd vene когда-нибудь. 
näitelauseid), üksnes Viidana keelejuhtidelt ei leia näiteid verbi rod'ida/ rod'izetta esialgsest tähendusest kaugenemise kohta.

'sündima': (Vi, VS) dī / vìdanan küläs rodizuin 'jaa, Viidana külas sündisin'; (Pü, VK) muamo oli täs rod'inu 'ema oli siin sündinud'

tuleviku koopula: (Ka-Li, AM) huomei minä rodimmos kod'is 'homme ma olen kodus'; (Pü, VS) sīh rod'ih kirikkö 'sinna tuleb kirik'; (Li-Pr, IT) jäl $i$ void rodih hüväd 'jälle võid saavad head'

liitpredikaadi osa: (Pü, VS) rod'i hüvä kons kai rod'i azuttu 'on hästi, kui kõik on tehtud'

Eeltoodut arvesse võttes võib väita, et Viidanale on omane liettä ning muudele murrakutele pigem rod'ida/rod'izetta. Siinkohal saab Viidana murraku puhul taas tõmmata paralleele põhjalüüdi murretega: ka näiteks Kujolal esineb rohkesti põhjalüüdi liettä-vorme (vt LmS 1944), kuid puuduvad vastavad näited Pühäjärvest ja Lid'žmist. Verbi rod'ida/rod'izetta kasutamine tuleviku väljendamiseks on aga ühisjoon muude kesklüüdi murrakute (v.a Viidana) ja Aunuse karjala murrakute vahel.

\subsubsection{Kontaktkeelte mõju kesklüüdi murdele}

Kesklüüdi murde kõnelejad on elanud pikka aega vähemusena venelaste ja Aunuse karjalaste seas. See on jätnud oma jälje ka lüüdi keelde. Järgnevalt toome siiski vaid mõned ilmekamad näited.

Kuna nii naabrite kui ka nooremate sugulastega suheldes kasutatakse igapäevaelus vene keelt, on ennekõike tunda vene keele mõju. Kõige silmatorkavam on see sõnavaras. Sageli pruugitakse venekeelsena kümnest suuremaid arvsõnu. Hea näide selle kohta on (Pü, VK) minul [---] rodih vośemsjat' nel' vuottə 'ma saan 84-aastaseks'. Näites (Pü, VS) tvatsat vtarovo ijunija voina zavod' $'$ '22. juunil algas sõda' on aga kogu määrsõnafraas venekeelne.

Kuigi tuleb ette juhtumeid, kus vene toorlaene kasutatakse koos venekeelse muutevormiga, nt (Pü, VK) täs minut krestīl'i (vrd vn крестили 'ristiti') 'siin mind ristiti', domineerib siiski omakeelne morfoloogia, seda ka toorlaenude puhul, nt (Li-Pr, IT) rǐžikkoi sobirā'it't'i 'riisikaid korjati', ut'š̀̀-tel'nítsayke l'ähtime 'õpetajaga läksime'. Tihti aga rakendatakse omakeelset morfoloogiat vene malli kohaselt, näiteks lauselõigus (Vi, NP) i russkijat külät i karelskijat 'nii vene kui ka 
karjala külad' kasutatakse omakeelset mitmuse tunnust $-t$, kuid vene nimisõnafraasi reeglite kohaselt: läänemeresoome omastavalise täiendi asemel kasutab kõneleja venepärast adjektiivatribuuti, mis ühildub põhisõnaga arvus.

Võib märgata, et sõna rõhk kipub laenude puhul siiski järgima omakeelset mudelit (pearõhk esimesel silbil), selleks võidakse sõna algusest jätta ära rõhuta silp, nt (Li-Pr, IT) no konz lontsapiäi lähtedä 'kui Olonetsi poole minnakse' või lihtsalt asetada rõhk esimesele silbile: (Li-Pr, IT) se·ležnoi do·roga 'raudtee', no vo·psē kaksin oli 'üldse oli kahekaupa'; (Ka-Li, AM) sid d'ermoškin meir oli na't'śal'n'ikke mama ro'sspiskan andoi 'siis Dermoškin oli meil ülemus, ema andis allkirja'.

Eriti tugev on vene mõju suletud sõnaklasside puhul. Näiteks modaalpartiklid on enamasti otse võetud vene keelest, nt kanеšno $(<\mathrm{vn}$ конечно) 'muidugi', dāže (< vn дажe) 'isegi', vrōde (< vn вроде) 'isegi, nagu', bud'ta $(<\mathrm{vn}$ бydbmo) jt. Kõnelejad lähevad sageli üle vene sidesõnasüsteemile, mis hõlmab sõnu, nagu $i(<\operatorname{vn} u), d a(<\operatorname{vn} \partial a)$, no $(<\operatorname{vn} н o), a(<\operatorname{vn} a)$, što (< vn чmo), štob (< vn чтобы), jesli (< vn если), tšem (< vn чем).

Vene keele tugev surve annab tunda segavormide esinemises, näiteks asesõnade süsteemis. Idapoolsemates läänemeresoome keeltes sageli esinevate eitavate umbmääraste asesõnade (nagu nt ni midä 'ei midagi') kõrval on meie materjalis sagedased ken-to-tüüpi umbmäärased asesõnad (vrd vn кmo-mo). Näiteks Viidana keelejuhi kõnest pärineb hän ǐ̌tū täga aina, kak bud'ta kedä-to vuottau 'ta istub siin, justkui ootaks kedagi'. Sama tüüpi vorm (ken-to tullou 'keegi tuleb') esineb ka Kindaha Aunuse karjalasel. Nende pronominaalsete segavormide kõrval, mis moodustavad terveid paradigmasid, leidub ka üksikuid eksootilisemaid moodustisi, nagu (Ka-Li, AM) libo mittād 'midagi, mida iganes'.

Teine segavormide liik puudutab järjendeid, milles sama funktsiooniga omakeelne ja võõrkeelne morfeem esinevad koos. Üks näide selle kohta on juba ülal mainitud topelteitus: (Pü, VS) a ńügü nave rna ni masta en ongittai 'aga nüüd arvatavasti ma ei oska õngitseda'; (Vi, NP) kutižmat mina ka ni t'iennü en 'Kutižmat mina ka ei teadnud'. Teine tüüpnäide on kaassõnafraasid, milles vene prepositsioon dubleerib lüüdi käänet. Näiteks täheldasime ühe Priäžä keelejuhi kõnes topeltseparatiivi, mis koosneb vene prepositsioonist ja lüüdi käändelõpust: vahnin iz mužikois 'meestest vanim'. Viidanas aga registreerisime lause sit läht'in opastumma na lehminke ruota 'siis läksin õppima lehmadega töötamist', kus vene 
instrumentaalne prepositsioon $n a$ dubleerib lüüdi komitatiivi funktsiooni. Kategooria topeltmarkeerimist esineb ka tingiva kõneviisi moodustamises, näiteks tingimuslauses (Pü, VS) eslib ńügü oldaiž 'kui praegu oleks' esineb nii vene konditsionaali kliitik $-b(\tilde{o})$ kui ka läänemeresoome sünteetiline konditsionaali tunnus - $i z ̌$-. Taolistes segavormides kombineeritakse sageli kahte morfoloogilist tüüpi - vene analüütilist ning lüüdi sünteetilist morfoloogiat. Ülal nimetatud samade kategooriate topeltmarkeerimine viitab sellele, et algupärase muutemorfoloogia läbipaistvus on kahanemas ning vormi ja funktsiooni vastandamises on ebakindlust. Ühtlasi on see aga vastuolus keelesurma teoreetilises kirjanduses esinenud väitega (Dressler 1981: 8), et hääbuvate keelte viimase põlvkonna kõnelejate grammatikat iseloomustab igasuguse liiasuse (ingl redundance) taandumine ja kadu toodud näited kõnelevad pigem süsteemsest liiasuse kasvust.

Aunuse karjala keele mõju on kõige tugevam Priäžä keelejuhtidel. Nagu juba ülal kirjeldatud, võib seal näiteks noomenite sõnalõpulise muutuse $a>e$ asemel kohata Aunuse karjala pärast muutust $a>u$, nt ilmu 'ilm', kagru 'kaer'. Samuti kasutatakse aunusemõjulist mitmuse 1. isiku pöördelõppu -mmo. Kuigi Pühäjärveski leidub näiteid sõnalõpulise muutuse $a$ $>u$ kohta ning mmo-lõpuliste 1 . isiku vormide kohta, domineerivad seal siiski lüüdipärane muutus $a>e$ ning mme-lõpuline mitmuse 1. isiku vorm.

Kesklüüdi murdele on omaseks peetud aunusemõjulist $n n U$-essiivi, Kuujärve ja põhjalüüdi murdest on aga üles kirjutatud ka vepsapärast n-lõpulist essiivi (Turunen 1946: 170). Meie keelejuhtide kõnes esineb mõlemat moodustusviisi: (Pü, VK) zōtehnikannu 'zootehnikuna', povarinnu 'kokana'; (Pü, VS) bohatannu 'rikkana'; (Vi, VS) bugalterannu 'raamatupidajana', prodavtsannu 'müüjana'; (Pü, VK) vratšan 'arstina'; (Vi, VS) splavšikan 'palgiparvetajana'. Seega võib täheldada $n$-lõpulise essiivi ala laienemist.

Interferents on kahtlemata mõlemasuunaline. Kuigi sageli arvatakse, et karjala murded on mõjutanud lüüdi keelt, võib täheldada ka vastupidist, st lüüdi jooni Aunuse karjala keeles. Näiteks konsonantühend $d n$ on säilinud sõna linn lüüdikeelses vastes, nt (Ka-Li, AM) lidǹaz 'linnas'. Kinnas (sm Kintahankylä, vn Киндасово) on kesklüüdi aladele lähedal asuv Aunuse karjala küla, mille murrakus esineb lüüdi jooni. Sealne Aunuse karjala keelejuht kasutas $d n$-ilist vormi lidnas 'linnas', mida üldiselt peetakse omaseks kesklüüdi murdele ja vepsa keelele. Põhjalüüdi murretes (v.a Nuomoila murdes) esineb sellel kohal järjekindlalt geminaat 
-nn (Turunen 1946: 27). Lüüdi mõju ilmnes ka Pühäjärves elaval Aunuse karjalasel, kes kasutas mitmuse 2. isiku vorme lüüdipäraselt tte-lõpulisena.

Pühäjärves oli meil võimalus elada kaasa oma keele erijoontest väga teadlike sõbrannade vestlusele, kui oma lüüdi sõbrannale tuli külla Aunuse karjalasest sõbranna. Viimane on kogu elu töötanud vene keele õpetajana, nii et huvi keelte vastu on suur. Ehkki aastakümneid sõbrannad ja iga päev tihedalt suhelnud, on mõlemad oma keelepruugi säilitanud.

Tabel 3. Lüüdi ja Aunuse karjala keele võrdlevaid näiteid

\begin{tabular}{|l|l|l|}
\hline \multicolumn{1}{|c|}{ Lüüdi keel (Pü, VS) } & \multicolumn{1}{|c|}{$\begin{array}{c}\text { Aunuse karjala keel } \\
\text { (Pü, TH) }\end{array}$} & \multicolumn{1}{c|}{ Eesti keel } \\
\hline hukke & hukku & hunt \\
\hline kaheksakümmen vuotte & kaheksakümmen vuottu & 80 aastat \\
\hline käded & käed & käed \\
\hline pitkäd d'algad & sūred jallad & pikad jalad \\
\hline ruadoitte & ruavoitte & töötasite \\
\hline müö ambuimme & müö ammuimmo & me lasksime, tulistasime \\
\hline rubedan lugemah & rubien lugemиah & hakkan lugema \\
\hline rod'ie iлde & iлda tuлоu & tuleb õhtu \\
\hline andaižin & andazin & annaksin \\
\hline
\end{tabular}

\subsection{Keelenäited}

Asjaolu, et kesklüüdi tekstide väljaandmine on teaduslikult otstarbekas ja ajakohane, kinnitab seni trükis ilmunud kesklüüdi tekstide nimekiri. Artikli alguses mainitud Genetzi uurimus (1872-1873) sisaldab Pühäjärve ja Viidana tekste. Mihail Georgijevski (1908) vene-karjala sõnaraamatu lõpus on neli lehekülge dialooge Pühäjärve murdes. Heikki Ojansuu, Juho Kujola, Jalo Kalima ja Lauri Kettuneni koostatud „Lüüdi keelenäidetes” (LK) on kesklüüdi tekste Pühäjärvest ja Priäžäst. Georgi Makarov on avaldanud priäžälase Anna Samsonova korjatud vanasõnu (Makarov 1971). Aleksander Barantsevi (1978) välja antud lüüdi keele näited sisaldavad tekste kesklüüdi Pelduoise külast. Pertti Virtaranta on välja andnud pühäjärvelase Anna Vasiljevna Tšesnakova juttude ja itkude kogumiku 
(Virtaranta 1994) ning Pertti Virtaranta ja Seppo Suhoneni toimetatud lähisugulaskeelte kogumikus on üks lühike tekst Pühäjärvest (LF: 33-37). Kovaleva ja Rodionova värskes sotsiolingvistilises töös leidub üks Pühäjärves lindistatud tekst (Kovaleva, Rodionova 2011: 110-117).

On märkimisväärne, et viimased väljaspool Venemaad avaldatud kesklüüdi tekstid pärinevad 1960. aastatest - nii Virtaranta (1994) kui ka LF-i kesklüüdi tekst on koostatud Pertti Virtaranta 1966. aastal tehtud lindistuste põhjal. Peale selle on enamik tekste pärit kesklüüdi murdeala lõunaosast, Viidanast pärit tekste on vähe. Kuna kesklüüdi murde lõplik hääbumine on pigem aastate kui aastakümnete küsimus, otsustasime avaldada mõne näite ekspeditsioonil kogutud materjalist. Keelenäidete valikus on tekste neljast meie käidud kesklüüdi piirkonnast - Lid'žmist, Pühäjärvest, Priäžäst ja Viidanast - kus lüüdi keelt tänapäeval veel räägitakse. Näidete valikul on oluliseks kriteeriumiks ka lindistuste sisu ja kvaliteet.

\subsubsection{Lid'žmi keelenäited (Li-Pr, IT)}

$E^{15}$ : a kui sinä olid laps oligo ližmas äijä rahvast? äijä ristkansu? 'Kui sina laps olid, kas siis oli Ližmas palju rahvast, palju inimesi?'

IT: ližmar oli äijä rahvàste / net'š́s / piäle t'ritsat'tī domo $\cdot v$ oli // no $i$ kaikie subbimb pereh oli vǐs henged / na šid nel'l'ä sigä mužikka kedä lapši ükši / kai oli piäle kümmenen hengen pereheiz / seitšemin lapšin oli vižzin lapšin oli // bo.hatad oldi [---] lapsis //

'Ližmal oli palju rahvast, üle 30 maja oli. No ja kõige väiksem pere oli viis inimest. No siis neli seal mees kellel üks laps. Kõigil oli üle 10 inimese peredes. Seitse last oli, viis last oli. Laste poolest oldi rikkad.'

ES: Ližman järvi - oligo see äijä, suur järvi? 'Ližma järv - kas see oli suur järv?'

IT: ližman d'ärvi on / lontsapiäi ettego käünü?? 'Ližma järv on, Olonetsi pool te pole käinud?'

ES: emme 'Ei.'

IT: ettego sinnepiäi mäne? 'Kas te sinnapoole ei lähe?'

ES: mänemme huomen 'Homme läheme.'

IT: da? d'ärvi meil oli vīš kilometrit potšstí / minga pidut // no konz

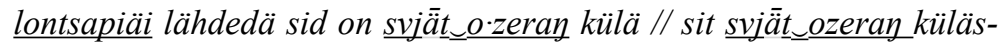

${ }^{15} \mathrm{ES}=$ Eva Saar. 
piäid edelle sinnä lähtedā sit kag_raz ližmin d'ärvi rodihe zen oigedal kädeл // kak raz doroge matkada sid d'ärven müöd-rindal // vezi oli ülin_hüvä nü̈ü̈de sīnd d'ärvespiäi svjät_ozerāa pogostā vedettä vette // 'Jah? Järv oli meil viis kilomeetrit peaaegu pikk. No kui Olonetsi poole minna, siis on Pühäjärve küla. Siis Pühajärve külast edasi sinna minna ja just täpselt Ližma järv tuleb paremat kätt. Tee läheb täpselt järve äärest. Vesi oli väga hea, nüüd siit järvest veetakse vett Pühäjärve kirikukülla.'

\subsubsection{Kaškana-Lid'žmi keelenäited (Ka-Li, AM)}

PK $^{16}$ : a sinä kävid koulussa Kaškanas? 'Kas sa käisid koolis Kaškanas?'

AM: kaškanaz // sigä oli seit'šsegümen kaksi taлoid gül'äz // a šimanistov tänne oli sin kakškümen kūs kilomedrid // pidi d'uosta // mäged mäged / endähäine starino heboir a elti da regeл / no vot // ei olnu maššin_do·rogoid / ńe bollu sigäl // vot muga elet'ti rahvaz //

'Kaškanas. Seal oli seitsekümmend kaks maja külas. Aga Šimaništost oli siia kakskümmend kuus kilomeetrit. Tuli joosta. Mäed, mäed, enne vanasti sõideti hobusega ja reega. No vot. Ei olnud autoteid ei olnud seal. Vot kuidas elas rahvas.'

PK: a koulu oli Šimanistos? 'Aga kool oli Šimaništos?'

AM: ei-ei // ei kоuли kaškanaz oli ńel'jä klassa suatteh oli // minä opastuin kaks pervoin da ftoroi.n karjaлaks // a kelle sano uskota ei što karjaлaks opastet'ti a opastet'ti karjaraks // sid t'ret'jem klassa minä opastuin veńe aks // d'üri kai veńe oli // se oli it'še vиoder / pa dritsat' [---] no ka voinad vaste // sid evakuā.tsijaz olimme // kirovskoiz oblast'iz / net'š́s olimme kолте vuotte //

'Ei-ei. Kooli oli Kaškanas neljanda klassini. Mina õppisin kaks, esimeses ja teises (klassis) karjala keeles. Kellele öelda - need ei usu, et karjala keeles õpetati, aga õpetati karjala keeles. Siis kolmandas klassis ma õppisin vene keeles. Just kõik vene (keeles) oli. See oli ise aastal [---] no enne sõda. Siis olime evakuatsioonis. Kirovi oblastis olime kolm aastat.'

a müö kod'ih tänne Gu evakuī-roit't'i ja tulimme kod'ih tulimme ka midäbi ni midä ni kuz // a kaškanas pid'i tōže dvesti grā̄andoi / d'auho no andet'ti leibäd ńe олn ei / nātšsit kūs_sada grammad d'auhod kilo leibäd pidi azuma vot sìden // dvesti gram andet'ti ka sit t'š́sotad d'älg päiväks

${ }^{16} \mathrm{PK}=$ Petar Kehayov. 
pidi tuoda // sìd midä pūttū süöimme //

'Kui evakueeriti ja me tulime koju, ei (olnud) mitte midagi mitte kuskil.

Kaškanas pidi samuti, kakssada grammi andis, no jahu anti, leiba ei olnud. Tähendab, kuussada grammi jahu (anti), kilo leiba pidi tegema vot siis. Kakssada grammi anti, siis jagu (norm, ports) järgmiseks päevaks [leiba] tuli tuua. Siis sõime, mis juhtus.'

kazvettā ned sigäl pistikäd nazivāalli // moižed nēt sit kerädämme kerädämme kevadeл ka олdu nituл kat'̌́s butked / kuivad butked / nit kerädämme siden survomme / petkerel humborei / sìden azutam tahtaste / mama azū da sìd neygosto paštetā / sin da hüväd d'auhot panda vähäińe sinne $i$ vot nin elimme muga // siden met's̈äz / ken / mama met'šäz ruaduoi hälle vośśsmso·t grā̄ jezli norma oli azunu ni ližättä sìhe stō grā̄ libo mittād // miulle kūštošt vuotta jo rodiheza / a meț̌̈äh ei odettu //

'Kasvavad need seal, pistikäd nimetati. Sellised need siis korjame, korjame, kevadel kui olid niidul putked, kuivad putked. Need korjame, siis jahvatame, nuiaga, uhmriga, siis teeme taignast, ema teeb sellisest küpsetatakse. Head jahu pannakse sinna vähe ja vot nii elasimegi. Siis kes metsas, ema töötas metsas, temale kaheksasada grammi (anti), kui normi oli töötanud, lisatakse sinna sada grammi või midagi. Mina saan juba kuueteistaastaseks, aga metsa ei võetud.'

\subsubsection{Pühäjärve keelenäited}

\subsubsection{1. (Pü, VS)}

PK: A kirkko on täs̄ lähellä? 'Aga kirik oli siin lähedal?'

VS: no meil_on prih̀od // kirikko rubetah stroimmah / enda vot täs rindaл oli meil kirikko / vot on kirikkö / sìh on riste pandu / pokлonnii krest veńäkse sanotah a / no müö l'ü̈diks sanomme riste / vot / $i_{\smile s i}$ id on nüugü_jo fundamentte zaleittu / splošnoi fundament / sìh rod'ih kirikkö / ka vot d'engad da_ei pokā oлеdag / no kirjutet't'ih gazettah ka t'üöt't'äha rahvas / t'üötäü / avutetah / štob`stroida / da`i müö keräžimme d'eygad //

'No meil on kogudus. Kirikut hakatakse ehitama. Enne vot siin vastas oli meil kirik, vot on kirik. Sinna on rist pandud. „Poklonnõi krest” nagu vene keeles öeldakse, aga meie lüüdi keeles ütleme „rist”. Vot, ja sinna on nüüd juba vundament valatud, kõva vundament. Sinna tuleb kirik. Aga vot raha ei ole praegu. No kirjutati lehte, et aidake. Rahvas saadab, aitavad, et ehitada. Ja me kogusime raha.'

PK: A oli vanha kirikkö? 'Oli vana kirik?' 
VS: dā / oli / dāže kaks oli / kakse // endä oli üks tägäл / kus̄_on pet'jan

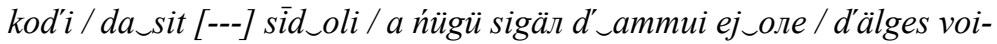
nad se rasrūǔzit't'i / no kai hän_d'o d'älges oli skлuadunnu / a täs̄ voinan aiga ралоi kiriǩ / vot tämä ūlit'śe on ńügü d'älges voinad kai stroittu / täs̄ еј_олnи ńi ühtä kod'id / kai paлoi / voinan_aiga /müö stroimmo d'o_d'älges voinad //

'Jaa, oli. Isegi kaks oli, kaks. Enne oli üks siin, kus on Petja kodu ja siis [---] seal oli. Aga nüüd seal ammu ei ole. Pärast sõda hävitati ära. No juba pärast oli laohoone. Aga siin sõja ajal põles kirik. Vot see tänav on nüüd pärast sõda kõik ehitatud. Siin ei olnud ühtegi maja, kõik põles sõja ajal. Me ehitasime juba pärast sõda.'

\subsubsection{2. (Pü, VK)}

PK: A külä oli tühjä? 'Kas küla oli tühi?'

VK: täs elet'tih / pitterispic ol'd'ih / pitteriskois / oblastispiä täss ol'd'ih eläjäd / hü̈ voinan_aiga he täss finskoid ne_ne voiskat tabat'tih da sìh d'ätet'ti / sanot'ti_što elägät te täs / kod'it ordah svobodnoet / no äi meiл poltet'tih / keski kai poltet'tih kod'id / no sanotah_što itše vrōde palaškanzi / no ambut'ti da kaik palaškanzi vot kirikkö paлoi / kai ne ne kohdat palet'tih sūrembat kod'id // no tulimme meidän bābuškan kod'i hengis oli dāıi meidän oli tōš / vot sit kod'ih omah tulimme //

'Siin elati. Peterburist olid, Peterburi oblastist olid siin elanikud. Nad sõja ajal siin need soome väed tabasid ja jäeti siia. Ütlesid, et elage te siin, kodud on vabad. No palju meil põletati. Keskel kõik kodud põletati. Öeldakse, et ise arvatavasti läksid põlema. No tulistati ja kõik läks põlema. Vot kirik põles. Kõik need kohad põlesid, suuremad kodud. No tulime, vanaema kodu oli alles ja meie oma oli ka. Vot siis oma koju tulime.'

PK: A kus se vahna pertti oli? 'Aga kus see vana maja oli?'

VK: vahna pert'ti meill_oli sürd'äs̄ / sürd'äs oli baban pert'ti / poikki järves //

'Vana maja oli meil Sürjäs. Sürjäs oli vanaema maja, üle järve.'

PK: Sürjäs? 'Sürjäs?'

VK: Sürjäs / sìd on meil külä ei sūri poikki järves / Sürjäs oli külä sigä / koi sigäl / no se kod'i d'älges ülen oli_d'o vahne / ritšit'tí / sit hüö täs ostet'tih toine // a meil mamar / hän miehele mäni / sìd oli täl ūlitšal kuš`škola on / täl ūlitšal / škol'noil oli tōže / kod'i / no puoli kod'id 
meil_oli / puoli kod'id ühte oli vel'l'el / puoli kod'id meil_oli // no vot / $k a$ müö sigäl elimme / vot / meid kaks tüttärtä jo mamaл oli sìd / ajoimme lidna elämän //

'Sürjäs. Seal on meil küla, mitte suur, üle järve. Sürjäs oli küla seal, maja seal. No see maja pärast oli väga vana. Lammutati. Siis nad ostsid siin teise, aga meil emal, ta läks mehele, siin oli sel tänaval, kus on kool. Sel tänaval, kooli tänaval, oli ka maja. No pool maja meil oli, pool ühel vennal oli, pool meil oli. No vot. Meie seal elasime. Vot. Meid kaks tütart juba emal oli seal. Läksime linna elama.'

\subsubsection{Priäžä keelenäited (Pr, KV)}

ES: kuin sinä sanod, oled sinä lüüdikkoi vai karjalain? 'Kuidas sa ütled, oled sa lüüd või karjalane?'

KV: minä olen l'ü̈d'ikkaiń / l'üd'ikkö / pühärves tōže l'üd'ikköd // v svjāt_ōzera //müö olemme karjalaized $i$ vsjō // opššie takō-je karjalaized

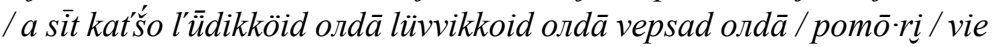
kedä sid / heid on äijü meidä // suomaлаizet tиоž теіл олdā [---] puole priäžässsä / matrossassāa oлemme l'üuvikkod / vieljärvel l'üvvikod / no vo·pše blīze èta l'üd'ikköd // ühtemoižed oлdā hü̈ / täs müö olemmo // a se net'š́s pohjoizes pomō'rị nazivāa.jetsa //

'Mina olen lüüd, lüüd. Pühäjärves on samuti lüüdid. Svjatozeras. Me oleme karjalased ja kõik. Üldine selline - karjalased. Aga siis, vaata, lüüdid on, livvikod on, vepsad on, pomoorid, veel kes siis, neid on palju, meid. Soomlased on meil ka. [---] Poole Priäžäni, Matrosõni oleme livvikod, Vieljärvel livvikod, sellele väga lähedased on lüüdid. Nad on ühesugused, siin me oleme. Aga seal põhjas nimetatakse - pomoorid.'

a viel'ärvez oli tietoińikad / iz nāšo ōpita // minun mama ülin äijä hampahat pakotet't'i // a sit sē hänen / muamo sanoi tietoinikar / meni tietoinikaлиo / èta takā.ja istō-rija prāvil'naja // mama minun mama meni / tüttöin vieri / ei äijü mama / meni tietoinikar // tietoiniko opī oli tietoińikko äijü tieț // sanoi lähtet kod'i / sinul sua taga rubie tuhizemā i äijä rubieš / net'š́eda / šum kak pa_kare ll'skī [---] ilma paha rodiei vot jemū. skāž- / ilmu ilmu // se sanoi katš́o älä d'älgei // ei kat'śsonu astui kod'ih ei kat'šsonu // d'älgeh sidä hampahat häne_ei pakotettu // i se se tietoiné sanoi sinu ei pakottā sinu lapsoil i sinu vunukkoil ei pakoteta I do sih por ńe znājem / ei müö tiedä hampahan pakkoi / vot tak //

'Aga Vieljärves olid teadjad, meie oma kogemusest (jutustan). Minu emal väga palju hambad valutasid. Aga siis tema, ema ütles teadjale, läks teadja juurde, see on selline tõestisündinud lugu. Minu ema läks 
tüdrukuna veel, ei olnud suur, läks teadja juurde. Teadja uuris, teadis palju. Ütles: „Lähed koju, sinul hakkab taga järvel tuhisema ja väga hakkas ..." no ,šum” kuidas on karjala keeles [---] ,paha ilm tuleb”, vot temale ütleb. Ilm, ilm. See ütles: „Ära vaata tagasi!” Ei vaadanud, astus koju, et vaadanud. Peale seda tal hambad ei valutanud. Ja see teadja ütles: „Sinul ei valuta, sinu lastel ja lastelastel ei valuta." Selle ajani meie ei tea, me ei tea hambavalu. Vot nii.'

\subsubsection{Viidana keelenäited}

\subsubsection{1. (Vi, VS)}

PK: A sinun muamo ja tuatto on Viidanas? 'Aga sinu ema ja isa on Viidanast?'

VS: vìdanan / vìdanan rahvas / $i$ muam i tuatta / muamo eli sel bokar d'oged / a iža el'i siga ülävidas //

'Viidana, Viidana rahvas. Nii ema kui isa. Ema elas sealpool jõge, aga isa seal Ülä-Viidanas.'

\section{PK: Üläviidanas? 'Ülä-Viidanas?'}

VS: dā da / $i$ vot nait'tih / $i$ toinen tošta tōže löüt'tih $i$ vot elet'tîh / nu_vot / i meil ižal da emäl meid on / oli vizi henged / vot / ei_joлe vai heygis poigad / tädä / vel'l'ed minun kuoli [---] a sizarəksat oлdah

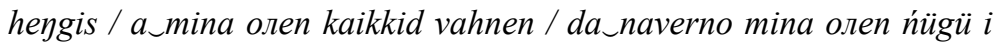
karjalaižis täss / vähä on karjalašte rahvaste nüugü / vot ei_joлe dāže mida neittsukoile sanoin / jo otutšilaś pagišta što ei_joлe keneクke pagišta / еi_jоле / tässä тіллаi rindaл eläü ristikanzu karjalaine no hän on tōže l'ūd'i- / ei tämä / lìvik //

'Jaa-jaa. Ja vot abiellusid, teineteist leidsid ja vot elasid. No vot. Ja meil isal ja emal meid on- oli viis hingelist. Vot ei ole ainult poisid elus. Seda, vennad mul surid. [---] Aga õekesed on elus. Aga mina olen kõige vanem. Ja ilmselt mina olen nüüd ka karjalastest siin [kõige vanem]. Vähe on karjalasi nüüd. Vot ei ole isegi, mida tüdrukutele ütlesin, juba olen võõrdunud [karjala keeles] rääkimisest, sest ei ole, kellega rääkida. Ei ole. Siin mul vastas elab inimene, karjalane, aga ta on ka lüüdi-, ei tema on livvik.' 


\subsubsection{2. (Vi, NP)}

PK: Kui äiju klassua sinä kävit? 'Kui mitu klassi sa käisid?'

NP: mina kävüin kūzi klassat kaikked / i ruodoh meid otprāvili / müö kaikkin olimme jo pererjoski / kümmene vuotta lähtimme pervijeh klassag // paha paha meid'än oli aigol / detstvo miul kai otńali / nälgäd ńäpišsimme //

'Mina käisin kuus klassi ainult ja meid saadeti tööle. Me olime kõigile juba ristiks kaelas. Kümneaastaselt läksime esimesse klassi. Paha-paha oli meil siis. Lapsepõlv võeti mult kõik ära. Nälg näpistas.'

PK: A sit ruozit? 'Aga siis töötasid?'

NP: a sit ruozimmə 'Aga siis töötasime.'

PK: A kossa sinä ruozit? Kolhozassa vai? 'Aga kus sa töötasid? Kolhoosis või?'

NP: i koлhozas pid'i ruota / meit po_komsamol'skim putovkam tü̈̈t'tih kолhozah / mina ruozin ferma / sit läht'in opastumma na lehminke ruota / obšem kui polozòtehnike mina ol'in //

'Ka kolhoosis pidi töötama. Meid komsomoli kaudu suunati kolhoosi. Mina töötasin farmis. Siis läksin õppima lehmadega töötama, põhimõtteliselt ma olin nagu pool-loomatehnik.'

\section{Kokkuvõte}

Kesklüüdi murre on vanema põlvkonna murre: kõige nooremad head kõnelejad on sündinud 1930. aastatel. Olgugi et Loode-Venemaa linnades ning Soomes elavate kesklüüdi murde kõnelejate arv on meile teadmata, võime ekspeditsioonil kogutud andmete põhjal väita, et 2012. aasta seisuga ei ületa ajaloolisel kesklüüdi alal elavate kesklüüdi murde kõnelejate arv suure tõenäosusega sadat inimest. Seega tuleb nentida, et see läänemeresoome murre on suremisstaadiumis. Kesklüüdi murre hääbub geograafiliste, majanduslike, demograafiliste ja ajalooliste tegurite koosmõjul, millest kaalukamad on ehk Petroskoi linna lähedus, piirkonna suur industrialiseeritus ja sellega kaasnenud suur sisseränne.

Kesklüüdi murre on nii fonoloogiliste kui ka morfoloogiliste tunnuste ning naabermurretest lähtuva mõju poolest üsna heterogeenne. Esitatud andmete põhjal on võimalik järeldada, et kõige rohkem isoglosse jookseb kesklüüdi põhjapoolseima murraku - Viidana murraku 
ja ülejäänud kesklüüdi murdeala vahel. Viidana murrak jagab mitmeid ühisjooni põhjalüüdi murrakutega, eriti Nuomoila murrakuga. Artiklis leiavad esmakajastust järgmised Viidana murraku ühisjooned põhjalüüdi murdega, mis ühtlasi eristavad seda murrakut ülejäänud kesklüüdi alast: * $t i>$ si muutus minevikuvormides, nõrgaastmelised isikuliste asesõnade mitmuse vormid, refleksiivse liite paigutamine enne isikulõppu ning verbi liettä kasutamine tuleviku väljendamiseks (ülejäänud murrakutes esineb vastavas funktsioonis rod'ida/rod'izetta-verb).

Kesklüüdi murrakute vaheliste piiride nihkumist on ühelt poolt võimendanud vene asustuse vahelekiilumisest tingitud saarestumine, teisalt aga ka üha sügavamale lüüdi alale tungiv Aunuse karjala keele mõju. Selle protsessi tänapäevased ilmingud on Aunuse karjala pärase mmo-lõpulise mitmuse esimese isiku kasutamine Priäžäs ja kohati Pühäjärveski ning muutus $a>u$ nominatiivis ja partitiivis teatud tingimustel, mida samuti kohtab peale Priäžä mõnevõrra Pühäjärveski (lüüdipärase $a>e$ asemel). Seega Pühäjärve piirkonna murrak on nivelleerumas Priäžä suunas, säilitades siiski oma kõige erandlikuma joone $-i$-lõpulised infinitiivid.

Surevaid keeli iseloomustab analoogiaseaduse suurenenud roll morfofonoloogias ja morfosüntaksis. Näiteks kesklüüdi ootamatu $j>d^{\prime}$ asendus $l$-i järel (ootuspärane oleks $l j>l^{\prime} l$ ) on seletatav $r j>r d^{\prime}$ asenduse analoogiaga, mis on omakorda seostatav sõnaalgulise $j>d^{\prime}$ asendusega. Teine kesklüüdi taandumise märke on samade kategooriate topeltmarkeerimine (näiteks topeltkonditsionaal, topeltinstrumentaal-komitatiiv või kohatähenduste topeltmarkeerimine), mis viitab sellele, et algupärase muutemorfoloogia läbipaistvus on kahanemas ning vormi ja funktsiooni vastandamises esineb ebakindlust. Tulemuseks on lüüdi-vene segakeel, milles vene analüütiline ja lüüdi sünteetiline morfoloogia esinevad sageli kõrvuti. Selliselt pakub kesklüüdi murde tänapäev väärtuslikku materjali keelesurma uurijatele, kuid ühtlasi kiirustab tagant keelt talletama, seni kuni veel leidub soravaid kõnelejaid. 


\section{Lühendid}

IndPrSg3 - indikatiivi preesensi singulari 3. pööre; IpsKndPr - impersonaali konditsionaali preesens; IpsKndPf - impersonaali konditsionaali perfekt; KndPf konditsionaali perfekt; KndPfNg - konditsionaali perfekti negatiiv; KndPr konditsionaali preesens; PlAd - pluurali adessiiv; PotSg3 - potentsiaali singulari 3. pööre; SgAbl - singulari ablatiiv; SgAd - singulari adessiiv; $\mathrm{SgEl}$ - singulari elatiiv; $\mathrm{SgIn}$ - singulari inessiiv; $\mathrm{SgP}$ - singulari partitiiv

\section{Kirjandus}

Barantsev 1978 = Александр П. Баранцев. Образцы людиковской речи (образцы корпуса людиковского диалекта). 1, Деревня Пелдожа и её окрестности. Петрозаводск: Карелия.

Bogdanova 2003 = Елена В. Богданова. Возвратное спряжение в диалектах карельского языка. Диссертация на соискание ученой степени кандидата филологических наук. Петрозаводск.

Campbell, Lyle, Martha C. Muntzel 1989. The structural consequences of language death. - Investigating Obsolescence. Studies in language contraction and death. Ed. by Nancy Dorian. (= Studies in the Social and Cultural Foundations of Language 7.) Cambridge, 181-196. http:// dx.doi.org/10.1017/CBO9780511620997.016.

Dorian, Nancy 1977. The problem of the semi-speaker in language death. Language Death. Ed. by Wolfgang Dressler, Ruth Wodak-Leodolter. (= International Journal of the Sociology of Language 12.) Hague, 23-32. http://dx.doi.org/10.1515/ijsl.1977.12.23.

Dressler, Wolfgang U. 1981. Language shift and language death - a protean challenge for the linguist. - Folia Linguistica 15 (1-2), 5-28. http:// dx.doi.org/10.1515/flin.1981.15.1-2.5.

Forsberg, Hannele 2003. Paths of development for modal meanings: Evidence from the Finnic potential mood. - Historical linguistics 2001. Selected papers from the 15th International Conference of Historical Linguistics, Melbourne, 13-17 August. Ed. by Barry J. Blake, Kate Burridge. Amsterdam: John Benjamins, 143-161.

Genetz, Arvid 1872-1873. Wepsän pohjoiset etujoukot. - Kieletär 1872: 4, $3-32 ; 1873: 5,3-26$.

Georgijevski 1908 = Михаил Д. Георгиевски. Русско-корельский словарь. Санкт-Петербург: Типография В. Д. Смирнова.

Itkonen, Terho 1971. Aunuksen äänneopin erikoispiirteet ja aunukselaismurteiden synty. - Virittäjä 2, 153-185.

Iva, Sulev 2007. Võru kirjakeele sõnamuutmissüsteem. (= Dissertationes philologiae Estonicae Universitatis Tartuensis 20.) Tartu. 
Kettunen, Lauri 1943. Vepsän murteiden lauseopillinen tutkimus. - SUST 86. Helsinki.

Kettunen, Lauri 1960. Suomen lähisukukielten luonteenomaiset piirteet. - SUST 119. Helsinki.

Kovaleva, Rodionova 2011 = Светлана В. Ковалева, Александра П. Родионова. Традиционное и новое в лексике и грамматике карельского языка (по данным социолингвистического исследования). Петрозаводск: Карельский научный центр.

Kujola, Juho 1932. Lyydiläiset. - Karjalan kirja. Toim. Iivo Härkonen. PorvooHelsinki, 518-530.

Laanest, Arvo 1975. Sissejuhatus läänemeresoome keeltesse. Eesti NSV Teaduste Akadeemia Keele ja Kirjanduse Instituut. Tallinn.

$\mathbf{L F}=$ Lähisukukielet. Finnic languages: Karelian, Ludic, Vepsian, Ingrian, Votic, Livonian. 1983. Toimittaneet Pertti Virtaranta ja Seppo Suhonen. Näytteitä uralilaisista kielistä III / The Uralic Languages. Examples of Contemporary Usage. Suomi 119: 3. Helsinki.

LK = Lyydiläisiä kielennäytteitä. Koonneet Heikki Ojansuu, Juho Kujola, Jalo Kalima ja Lauri Kettunen.(= Suomalais-Ugrilaisen Seuran Toimituksia 69.) Helsinki 1934.

LmS = Lyydiläismurteiden sanakirja. 1944. Toimittanut ja julkaissut Juho Kujola. (= SUS, Lexica Societatis Fenno-Ugricae IX.) Helsinki.

Majtinskaja 1973 = Клара Е. Майтинская. Будущее время в финно-угорских языках. - СФУ IX, 81-90.

Makarov, Grigori N. 1971. Sananlaskuja Aunuksen Prääsästä, kerännyt Anna T. Samsonova, julkaissut ja selityksin varustanut G. N. Makarov. (= Suomalais-Ugrilaisen Seuran Aikakauskirja 71.) Helsinki.

Mamontova, Nina 2002. Vanhan kylän uusi perinne. - Carelia 6, 30-31.

Metslang, Helle 1996. The Development of the Futures in the Finno-Ugric Languages. - Estonian: Typological Studies I. Ed. by Mati Erelt. (= Publications of the Department of Estonian of the University of Tartu 4.) Tartu, 123-144.

Mullonen 2008 = Ирма И. Муллонен. Топонимия Заонежья: Словарь с историко-культурными комментариями. Российская Академия наук. Карельский научный центр. Петрозаводск.

Pahomov, Miikul 1992. Lyydiläiskysymys. - Kieliposti 3, 9-12.

Pahomov, Miikul 1995. Lyydiläiskysymys, kieli ja historiaa. - Itämerensuomalaisten kansojen historiasta. - Karjalan Heimo 7/8, 109-110.

Pahomov, Miikul 2003. Salaperäisten lyydiläisten heimo. - Alkukoti. (= Helsingin yliopiston ylioppilaskunnan sukukansavaliokunnan lehti 5.) Helsinki: Helsingin Yliopisto, 31-35.

Pahomov, Miikul 2011. Kuujärven lyydiläisteksteja. - SUST 263. Helsinki. 
Palmeos, Paula 1962. Karjala valdai murrak. Eesti NSV Teaduste Akadeemia Keele ja Kirjanduse Instituut. Tallinn.

Sasse, Hans-Jürgen 1992. Language decay and contact-induced change: Similarities and differences. - Language Death. Factual and Theoretical Explorations with special reference to East Africa. Ed. by Matthias Brenzinger. Berlin: Mouton de Gruyter, 59-80. http://dx.doi. org/10.1515/9783110870602.59.

SNMKA = Список населенных мест Карельской АССР (по материалам переписи 1926 года) / Karjalan A.S.N.T:n asuttujen paikkojen luettelo (Vuoden 1926 väestönlaskun ainehiston mukaan). Karjalan A.S.N.T.: Tilastohallinnon laatima; http://www.genealogia.fi/hakem/asnt1926.pdf.

Zaiceva 2002 = Нина Г. Зайцева. Вепсский глагол. Российская Академия наук. Карельский научный центр. Петрозаводск.

Zaikov $2000=$ Пекка М. Зайков. Глагол в карельском языке. Российская Академия наук. Карельский научный центр. Петрозаводск.

Zaikov, Pekka 2012. Karjala keel. (Loengud Tartu Ülikoolis oktoobris 2012.)

Tauli, Valter 1966. Structural tendencies in Uralic languages. The Hague: Mouton.

Tunkelo, Eemil A. 1946. Vepsän kielen äännehistoria. (= Suomalaisen kirjallisuuden seuran toimituksia 228.) Helsinki.

Turunen, Aimo 1946. Lyydiläismurteiden äännehistoria I. Konsonantit. - SUST 89. Helsinki.

Turunen, Aimo 1947. Lyydin asema vepsän ja karjala-aunuksen välimurteistona. - Virittäjä 1, 1-12.

Turunen, Aimo 1950. Lyydiläismurteiden äännehistoria II. Vokaalit. - SUST 99. Helsinki.

Virtaranta, Pertti 1972. Die Dialekte des Karelischen. - SFU 1, 7-27.

Virtaranta, Pertti 1994. Lyydiläisiä tekstejä VI: Anna Vasiljevna Tšesnakovan kerrontaa ja itkuvirsiä. - SUST 218, Helsinki. 


\section{Lisa 1. Fotod}

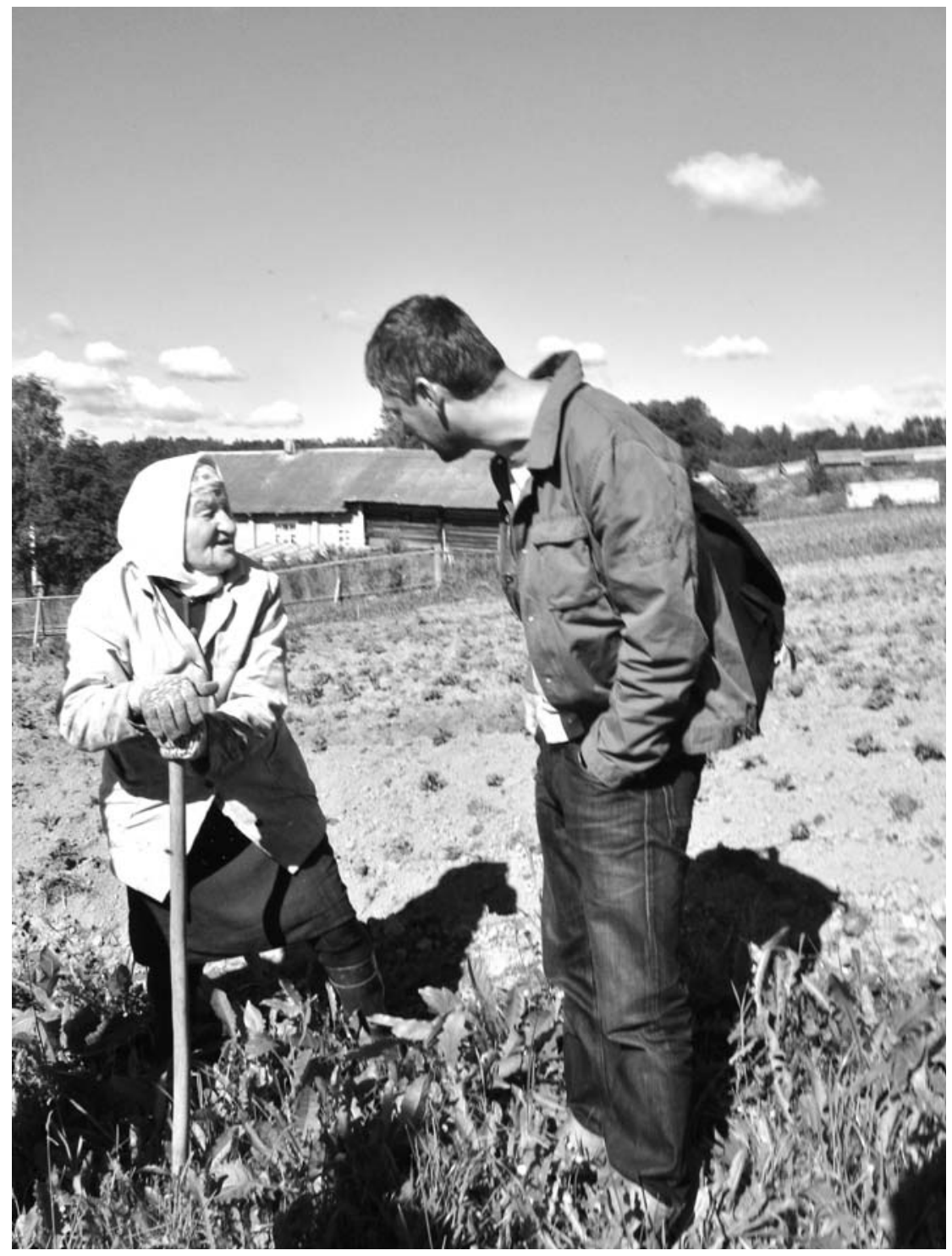

Lid'žmi keelejuht oma põllul 


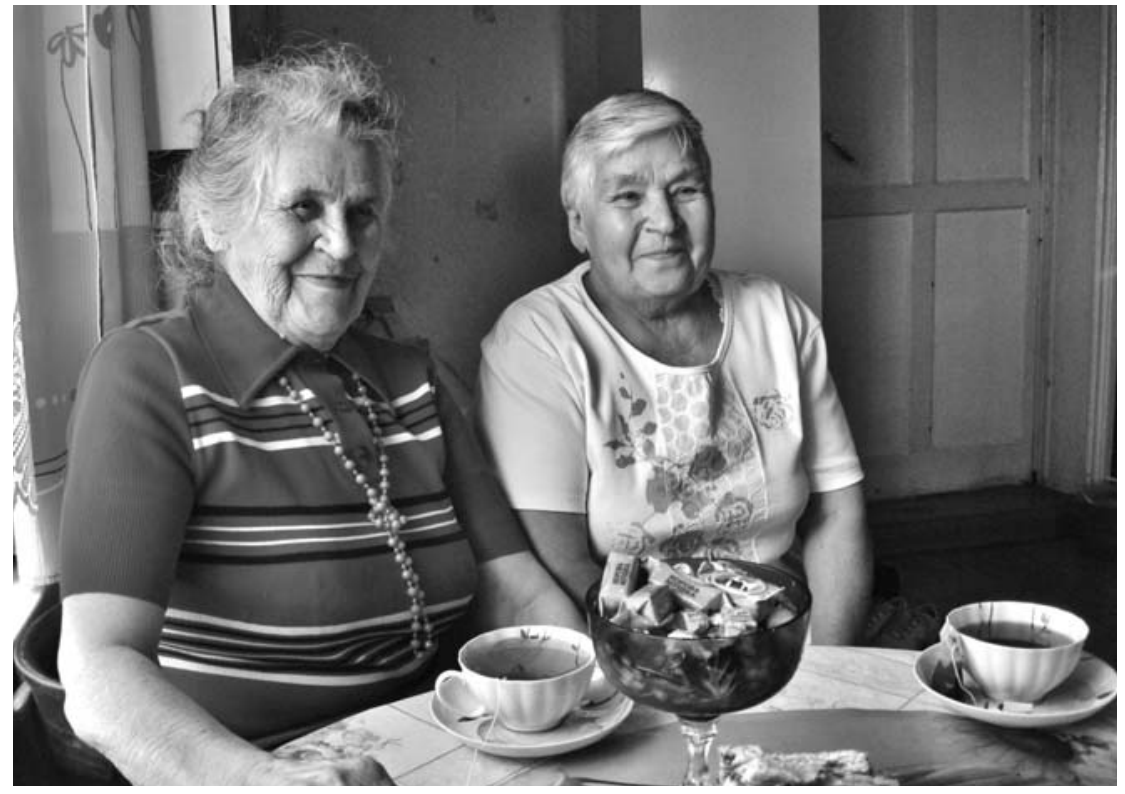

Pühäjärve keelejuhid

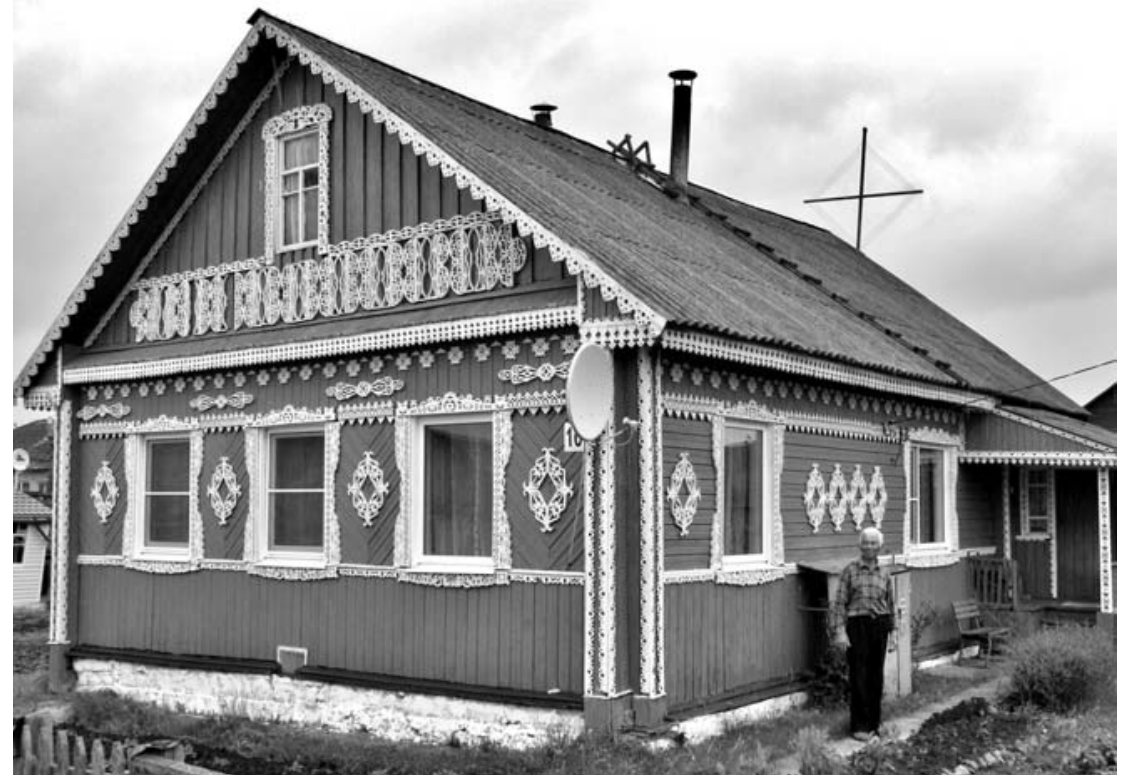

Priäžä keelejuht oma koduõues 


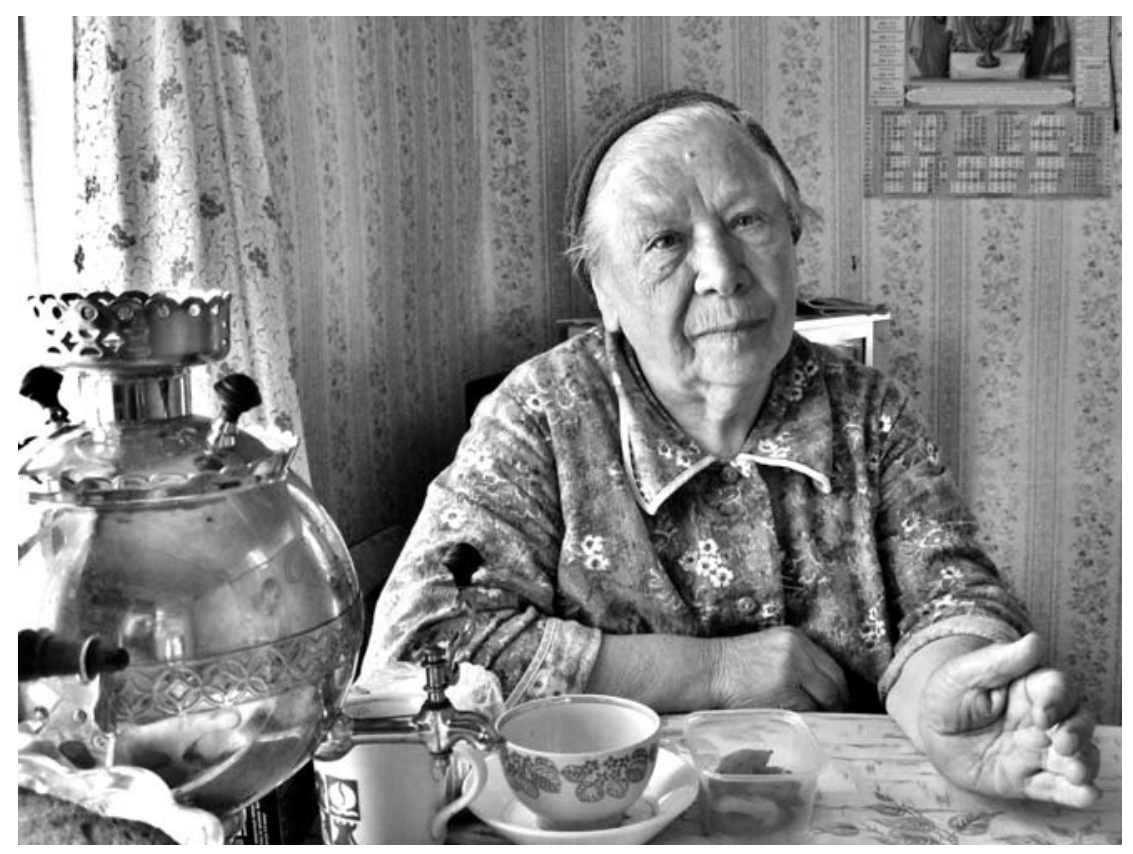

Viidana keelejuht oma kodus 


\title{
In the footsteps of vanishing Central Lude in summer 2012
}

\author{
Petar Kehayov, Eva Saar, \\ Miina Norvik, Andres Karjus
}

Lude (or Ludic) is one of the most endangered and least documented Finnic languages. The article presents the results of a research expedition to the Central Lude area, carried out in June 2012 by a group of linguists from the University of Tartu. Although the discussion is intended chiefly for a linguistic audience, our search for causes of the rapid decline of Central Lude addresses a number of issues relevant to neighbouring fields, such as history, ethnology, and the sociology of language.

The extinction of Central Lude is a process closely related to Soviet and post-Soviet realities. Its structural dimensions can at least partly be construed as an outcome of a set of extra-linguistic (geographical, economic, demographic, and historical) factors.

The article provides an overview of the contemporary structure of Central Lude. Considering evidence from all subdialects - Viidan, Priäžä, Pühäjärvi, Lid'žmi, and Kaškan - we arrive at the conclusion that the Central Lude dialect area is highly heterogeneous. This is due to the close connections between the Viidan subdialect and the North Lude dialects, especially with the subdialect of Nuomoila, and extensive dialect levelling between the Priäžä subdialect and the neighbouring Olonets dialects.

Special attention is paid to the contacts of the Central Lude dialect with the dominant languages of the area. Apart from the enormous structural impact of Russian, contemporary Central Lude exhibits characteristics typical of language decay, such as an increase in analogical generalization and a co-occurrence of synthetic and analytic structures used in the expression of the same meaning. The paper also presents a collection of transcribed texts from the major Central Lude subdialects.

Keywords: descriptive linguistics, endangered languages, language contact, language documentation, Lude, phonology, morphology 
Petar Kehayov

eesti ja üldkeeleteaduse instituut

Tartu Ülikool

Jakobi 2

51014 Tartu

petar.kehayov@ut.ee

Eva Saar

eesti ja üldkeeleteaduse instituut Tartu Ülikool

Jakobi 2

51014 Tartu

eva.saar@ut.ee

Miina Norvik

eesti ja üldkeeleteaduse instituut

Tartu Ülikool

Jakobi 2

51014 Tartu

miina.norvik@ut.ee

Andres Karjus

eesti ja üldkeeleteaduse instituut

Tartu Ülikool

Jakobi 2

51014 Tartu

andres.karjus@ut.ee 